\title{
The Current Host Range of Hepatitis E Viruses
}

\author{
Scott P Kenney
}

Food Animal Health Research Program, Department of Veterinary Preventive Medicine, The Ohio State University College of Veterinary Medicine, Wooster, OH 44691, USA; kenney.157@osu.edu

Received: 24 April 2019; Accepted: 14 May 2019; Published: 17 May 2019

\begin{abstract}
Hepatitis E virus (HEV) is an emerging zoonotic pathogen transmitting both human to human via the fecal oral route and from animals to humans through feces, direct contact, and consumption of contaminated meat products. Understanding the host range of the virus is critical for determining where potential threats to human health may be emerging from and where potential reservoirs for viral persistence in the environment may be hiding. Initially thought to be a human specific disease endemic to developing countries, the identification of swine as a primary host for genotypes 3 and $4 \mathrm{HEV}$ in industrialized countries has begun a long journey of discovering novel strains of HEV and their animal hosts. As we continue identifying new strains of HEV in disparate animal species, it is becoming abundantly clear that HEV has a broad host range and many of these HEV strains can cross between differing animal species. These cross-species transmitting strains pose many unique challenges to human health as they are often unrecognized as sources of viral transmission.
\end{abstract}

Keywords: hepatitis E virus; HEV; host range; zoonosis; animals; virus transmission

\section{Introduction}

Hepatitis E virus (HEV) is a single-stranded positive-sense RNA virus thought to be the leading cause of acute viral hepatitis in humans throughout the world [1]. The exact host range of HEV remains muddled, primarily due to the discrete nature of HEV infections. HEV often presents undetectable pathology in infected organisms. Replication levels are typically low and shedding of the virus is sporadic, making the technical and cost to benefit aspects involved in the extensive screening necessary for detecting HEV RNA in all potential host species prohibitive. A single virus serotype among all known strains makes distinguishing infection by differing strains difficult. However, recent data showing newly discovered HEV homologues in fish [2], amphibians [3], moose [4], kestrels [5], and other diverse species suggests the family Hepeviridae might possess a host range with similarity to the Herpesvirales order which include numerous viruses infecting humans and almost all animal species, including insects, fish, mollusks, reptiles, birds, and mammals [6]. The unique aspects of HEV infection might simply hide its full prevalence. As we continue to evolve more efficient and advanced methods to screen for RNA virus populations and expand our HEV phylogenetic trees, we will inevitably find even more members of the Hepeviridae family and their host species, increasing the known host range of the virus.

\section{Background and Significance}

$\mathrm{HEV}$ is a substantial human pathogen. In areas where adequate sanitation and clean water are lacking, such as in the developing world or in areas with geopolitical conflicts, there have been numerous instances of large-scale HEV outbreaks involving tens of thousands of individuals [7-9]. As our understanding of HEV has expanded, it is now recognized as an emerging zoonotic disease prevalent throughout the world $[10,11]$. HEV is increasingly being recognized as a threat to 
immunocompromised populations, including patients receiving organ transplantations [12,13], infected with human immunodeficiency virus [14], battling cancer [15], among others. Understanding the host range of $\mathrm{HEV}$ is critical to identifying potential transmission routes to humans, species that serve as reservoirs of viral persistence in the environment, and as potential hosts where HEV can mutate and become even more virulent.

\section{Hepatitis E Virus Host Range}

\subsection{Factors Determining HEV Host Range}

Viral host range is determined by many different factors, both intrinsic and extrinsic. Intrinsic factors to the virus, such as genetic traits encoding advantageous viral proteins, determine its fitness in individual hosts [16]. Intrinsic factors contributing to the host range of HEV include its ability to bind and enter host cells, successful interfacing with the host cell replication machinery, presence of negative regulatory factors, and ability to overcome the host's innate immune defenses. The ability of HEV to exist as both lipid-associated and naked virus particles likely plays a role in immune system avoidance (enveloped virions) while maintaining stability in the environment (naked virions). The host receptor for $\mathrm{HEV}$ remains elusive, possibly complicated by differing entry mechanisms between envelope-associated and naked virions [17]. Without knowing a definitive entry receptor or set of receptors, predicting susceptible hosts through in silico modeling is impossible. Host factors necessary for efficient viral replication remain understudied owing to a lack of robust cell culture systems across differing strains [18]. From a mix of in vitro and in vivo data numerous host cellular proteins are known to be altered during HEV infection. These include host proteins involved in metabolism, cholesterol/lipid metabolism, inflammatory/immune responses, and cytoskeleton/trafficking [19]. HEV is reliant upon the host transcription and translational machinery to replicate and efficiently make viral protein [20]. How open reading frame 1(ORF1) — host protein interactions differ between host cells of differing species has not been studied. Unlike known negative host restriction factors in human immunodeficiency virus replication, such as apolipoprotein B mRNA-editing enzyme 3G (APOBEC-3G) or tripartite motif-containing protein 5 (TRIM $5 \alpha$ ) and others [21-23], similar restriction factors have yet to be assessed for HEV but may contribute to host range. Finally, the host immune response, both innate and adaptive, likely play roles in limiting the host range of HEV. Species capable of mounting functional and lasting immune responses are less likely to serve as reservoir host species, as HEV appears to be particularly susceptible to host-mediated viral clearance with $>98 \%$ of human cases self-resolving [24]. Extrinsic factors relating to ecology and epidemiology also play significant roles in HEV host range [16]. Examples of extrinsic factors altering HEV host range include the geographic distribution of HEV isolates. Genotype $1 \mathrm{HEV}$ is predominantly spread throughout Africa, Asia, and the Middle East. Genotype 2 is limited to Africa and Mexico. Genotype 3 is the predominant strain circulating in North America, South America, and Europe but also has been found overlapping with genotype 4 in southern and eastern Asia. Genotype $4 \mathrm{HEV}$ is primarily found in Asia with some overlap in Europe. This geographic limitation is also likely a product of immunological cross-protection by predominant circulating strains. For example, if a region has endemic genotype $1 \mathrm{HEV}$ circulating that region is less likely to find genotype 3 or $4 \mathrm{HEV}$ isolates. This phenomenon is likely due to the timing and probability of initial strain exposure coupled with generation of a cross-protective immune response slowing introduction of different strains to that region [25].

\subsection{Serological Detection}

When searching for HEV in new animal species there are two primary methods used for detecting hosts exposed to the virus. Serological testing entails searching for host specific antibodies to the HEV capsid protein utilizing methods such as enzyme linked immunosorbent assays (ELISAs). These assays are thought to work well for broad detection of previous or ongoing HEV infections as there has only been a single serotype attributed to HEV [26,27]. Serological analyses have indicated infections 
with HEV or HEV-related viruses in a broad range of different animal species. Besides humans, HEV antibodies have been detected in farmed domestic animals, companion animals, laboratory animals, wild animals, and even animals from zoological parks. Serological data does require careful interpretation and should be accompanied by corroborating evidence such as detection of RNA. The presence of only a single serotype of HEV does not allow for designation of the HEV strain to which the animal was exposed without further confirmatory tests. Data presented based solely on seropositivity suggests HEV exposure but is not conclusive. Additionally, HEV ELISA assays have been developed independently in many labs with noted variability between lab groups making data difficult to compare between research groups. Finally, there have been reports of HEV positive ELISA results with the serum containing HEV neutralizing antibodies in the apparent absence of HEV genomes throughout the animal's life [28]. These results suggest the existence of unknown etiological agents that can generate cross-reacting, HEV-neutralizing antibodies in the absence of HEV infection [28]. Finally, the genetic heterogeneity of HEV does not exclude the possibility that divergent strains may have developed a different serotype that has yet to be detected.

\subsection{RNA Detection}

Utilization of reverse transcription polymerase chain reaction (RT-PCR) to directly detect HEV viral genomes is a critical step to diagnosing HEV infections. RT-PCR coupled with DNA sequencing allows the investigator to distinguish between HEV species and strains by genotyping. Simply detecting HEV RNA in fecal or whole organismal samples is also not a definitive indicator of host range or susceptibility. This is evidenced by detection of genotype 3 HEV RNA in mollusks and from vegetables $[29,30]$. These organisms are not thought to be true hosts for HEV replication but can become contaminated and harbor infectious virus as a potential pass through vector. The ability to detect HEV RNA in host plasma rather than in fecal samples or coupling RNA positive fecal data with HEV antibody seropositivity is a stronger indicator that a host is indeed susceptible to HEV replication. The only three definitive ways to show an organism is truly susceptible to HEV are to look for negative-stranded RNA replication intermediates in infected tissues, to show cell lines derived from the suspect species are capable of replicating HEV, or via experimental infection by showing viremia and virus shedding can persist longer than initial inoculum passing through the host. Many of these methods are very intrusive to the host species rendering them unable to be performed in totality. Hurdles such as necessary tissue samples being difficult to obtain, cell lines unavailable for many animal species, suspect animals themselves are rare and unavailable for experimental infection, and for other reasons. This leads to most of our knowledge relying on the combination of RNA and antibody detection to suggest a species is potentially a host for HEV infection. Frequent and continuous detection of specific HEV types in the same species crossing different geographical areas clearly indicates a true animal reservoir as exemplified by domestic pigs, wild boars, chickens, and rats. In other animal species where HEV is detected sparsely, this suggests spillover infections rather than a true reservoir host. For many animal species, no systematic studies on HEV infections are available, making many of the animals listed throughout Table 1 potential HEV hosts rather than true hosts. A combination of serology, RNA detection, experimental infection, confirmation of viral replication, and multiple detections of HEV in a specified host should be carefully considered before declaring the animal a true host. 


\subsection{Orthohepevirus A}

3.4.1. Genotypes 1 and 2 Are Believed to Be Restricted to Higher Primates and Thought to Have Adapted Specifically within Humans

Primate species including rhesus monkeys (Macaca mulatta), cynomolgus monkeys (Macaca cynomolgus), chimpanzees (Pan troglodytes), squirrel monkeys (Saimiri sciureus), patas monkeys (Erythrocebus patas), Eastern owl monkeys (Aotus trivergatus), moustached tamarins (Saguinus mystax mystax), and vervet monkeys (Chlorocebus pygerythrus) are susceptible to experimental infection with the Sar-55 (genotype 1) and/or Mex-14 (genotype 2) (Table 1). Genotype $1 \mathrm{HEV}$ is seen as the primary circulating HEV strain causing human disease in the developing world with many full-length viral sequences being deposited in Genbank [31]. However, genotype $2 \mathrm{HEV}$ does currently remain in circulation as a threat to human health having been detected in a recent outbreak in Nigeria [32]. How genotypes 1 and $2 \mathrm{HEV}$ remain endemic in the absence of non-primate animal reservoirs remains unknown. To date, only a single report of genotype $1 \mathrm{HEV}$ infecting outside of a primate species exists. Horses (Equus caballus ferus) in Egypt had an HEV antibody seroprevalence of 13\% and 4\% of screened samples were HEV RNA positive. Phylogenetic comparison of a 253-bp gene fragment sequence placed these HEV strains within the genotype 1 lineage [33]. Until more thorough analysis of potential secondary host susceptibility is undertaken, genotypes 1 and 2 HEV appear to be limited to higher primates, except in potentially rare instances where close contact of humans with domesticated animals may lead to some crossover exposure and ability of the virus to pass through hosts, such as horses. 
Table 1. Host Range for Orthohepevirus A.

\begin{tabular}{|c|c|c|c|c|c|}
\hline \multicolumn{6}{|c|}{ Animals Susceptible to Orthohepevirus A Infection } \\
\hline Animal Species & $\begin{array}{l}\text { Scientific Name } \\
\text { Order }\end{array}$ & Genotype & $\begin{array}{l}\text { Serology/Genome } \\
\text { Detection }^{\mathrm{a}}\end{array}$ & Infection Type & References \\
\hline African green monkey & $\begin{array}{l}\text { Chlorocebus sabaeus } \\
\text { Primate }\end{array}$ & HEV 1-2 & $+/ \mathrm{ND}$ & Experimental & Doceul et al. [34] \\
\hline American bison & $\begin{array}{l}\text { Bison bison } \\
\text { Artiodactyla }\end{array}$ & $?^{\mathrm{b}}$ & $+/-$ & Natural & Dong et al. [35] \\
\hline Asiatic black bear & $\begin{array}{l}\text { Ursus thibetanus } \\
\text { Perissodactyla }\end{array}$ & HEV 4 & $\mathrm{ND} /+$ & Natural & Zhang et al. [36] \\
\hline Bactrian camel & $\begin{array}{l}\text { Camelus bactrianus } \\
\text { Artiodactyla }\end{array}$ & HEV 8 & $+/+$ & Natural & Woo et al. [37], Rasche et al. [38] \\
\hline Bonnet macaque & $\begin{array}{l}\text { Macaca radiata } \\
\text { Primate }\end{array}$ & HEV 1 & $+/+$ & Natural & Arankalle et al. [39] \\
\hline Bottlenose dolphin & $\begin{array}{l}\text { Tursiops truncatus } \\
\text { Cetacea }\end{array}$ & HEV 3 & $+/+$ & Natural & Montalvo Villalba et al. [40] \\
\hline Cape buffalo & $\begin{array}{l}\text { Syncerus caffer } \\
\text { Artiodactyla }\end{array}$ & $?^{\mathrm{b}}$ & $+/ \mathrm{ND}$ & Natural & El-Tras et al. [41] \\
\hline Cat & $\begin{array}{l}\text { Felis catus silvestris } \\
\text { Carnivora }\end{array}$ & $?^{\mathrm{b}}$ & $+/-$ & Natural & Liang et al. [42], Mochizuki et al. [43] \\
\hline $\begin{array}{l}\text { Dairy cattle, yellow, Holstein } \\
\text { Frisian }\end{array}$ & $\begin{array}{l}\text { Bos Taurus primigenius } \\
\text { Artiodactyla }\end{array}$ & $\operatorname{HEV} 4, ?^{b}$ & $+/+$ & Natural & $\begin{array}{c}\text { Arankalle et al. [44], El-Tras et al. [41], Yan et al. [45], } \\
\text { Huang et al. [46] }\end{array}$ \\
\hline Chimpanzee & $\begin{array}{l}\text { Pan troglodytes } \\
\text { Primate }\end{array}$ & HEV 1-4 & $+/+$ & $\begin{array}{l}\text { Experimental } \\
\quad \text { Natural }\end{array}$ & $\begin{array}{l}\text { Yu et al. [47], Arankalle et al. [48], Meng et al. [49], } \\
\text { Yugo et al. [50], Zhou et al. [51], Spahr et al. [52] }\end{array}$ \\
\hline Clams (Yamato-shijimi) & $\begin{array}{l}\text { Corbicula japonica } \\
\text { Veneroida }\end{array}$ & HEV 3 & $\mathrm{ND} /+$ & Natural & Li et al. [53] \\
\hline Clouded leopard & $\begin{array}{l}\text { Neofelis nebulosa } \\
\text { Carnivora }\end{array}$ & HEV 4 & $\mathrm{ND} /+$ & Natural & Zhang et al. [36] \\
\hline Crowned crane & $\begin{array}{l}\text { Balearica regulorum } \\
\text { Gruiformes }\end{array}$ & HEV 4 & $\mathrm{ND} /+$ & Natural & Zhang et al. [36] \\
\hline Cynomolgus macaque & $\begin{array}{l}\text { Macaca fascicularis } \\
\text { Primate }\end{array}$ & HEV $1-5,8$ & $+/+$ & $\begin{array}{l}\text { Experimental } \\
\text { Natural }\end{array}$ & $\begin{array}{l}\text { Balayan et al. [54], Tsarev et al. [55], Bradley et al. [56], } \\
\text { Aggarwal et al. [57], de Carvalho et al. [58], Li et al. } \\
\text { [59], Wang et al. [60] }\end{array}$ \\
\hline Dog & $\begin{array}{l}\text { Canis lupis familiaris } \\
\text { Carnivora }\end{array}$ & HEV $4 ?^{b}$ & $+/-$ & Natural & $\begin{array}{c}\text { Liu et al. [61], Liang et al. [42], McElroy et al. [62], } \\
\text { Arankalle et al. [44] }\end{array}$ \\
\hline Domestic Pig & $\begin{array}{l}\text { Sus scrofa domestica } \\
\text { Artiodactyla }\end{array}$ & HEV 3,4 & $+/+$ & $\begin{array}{l}\text { Experimental } \\
\text { Natural }\end{array}$ & Meng et al. [63], \\
\hline Donkey & $\begin{array}{l}\text { Equus africanus } \\
\text { Perissodactyla }\end{array}$ & HEV 3 & $\mathrm{ND} /+$ & Natural & Garcia-Bocanegra et al. [64] \\
\hline Dromedary camel & $\begin{array}{l}\text { Camelua dromedarius } \\
\text { Artiodactyla }\end{array}$ & HEV 7 & $+/+$ & Natural & Woo et al. [37], Rasche et al. [38] \\
\hline Eastern owl monkey & $\begin{array}{l}\text { Aotus trivirgatus } \\
\text { Primate }\end{array}$ & HEV 1, 2 & $+/+$ & Experimental & Yugo et al. [40], Ticehurst et al. [65] \\
\hline
\end{tabular}


Table 1. Cont

\begin{tabular}{|c|c|c|c|c|c|}
\hline \multicolumn{6}{|c|}{ Animals Susceptible to Orthohepevirus A Infection } \\
\hline Animal Species & $\begin{array}{l}\text { Scientific Name } \\
\text { Order }\end{array}$ & Genotype & $\begin{array}{c}\text { Serology/Genome } \\
\text { Detection }^{\mathrm{a}}\end{array}$ & Infection Type & References \\
\hline European brown hare & $\begin{array}{l}\text { Lepus europaeus } \\
\text { Lagomorpha }\end{array}$ & HEV $3 ?^{b}$ & $+/-$ & Natural & Hammershmidt et al. [66] \\
\hline Farmed mink & $\begin{array}{l}\text { Neovison vison } \\
\text { Carnivora }\end{array}$ & HEV 3 & $\mathrm{ND} /+$ & Natural & Xie et al. [67] \\
\hline Goat & $\begin{array}{l}\text { Capra hircus aegagrus } \\
\text { Artiodactyla }\end{array}$ & HEV 3,4 & $+/+$ & Natural & $\begin{array}{l}\text { Peralta et al. [68], El-Tras et al. [41], Sanford et al. [69], } \\
\text { Di Martina et al. [70], Li et al. [71], Long et al. [70] }\end{array}$ \\
\hline Gray langur & $\begin{array}{l}\text { Semnoppithecus entellus } \\
\text { Primate }\end{array}$ & HEV 1 & $+/+$ & Natural & Arankalle et al. [39] \\
\hline Himalayan griffon & $\begin{array}{l}\text { Gyps himalayensis } \\
\text { Accipitriformes }\end{array}$ & HEV 3 & $\mathrm{ND} /+$ & Natural & Li et al. [72] \\
\hline Horse & $\begin{array}{l}\text { Equus caballus ferus } \\
\text { Perissodactyla }\end{array}$ & HEV 1,3 & $+/+$ & Natural & Saad et al. [33], Zhang et al. [73] \\
\hline Human & $\begin{array}{l}\text { Homo sapiens } \\
\text { Primate }\end{array}$ & HEV $1-4,7$ & $+/+$ & $\begin{array}{c}\text { Natural } \\
\text { Experimental }\end{array}$ & $\begin{array}{l}\text { Balayan et al. [54], Arankalle et al. [74], Huang et al. } \\
\text { [75], Meng et al. [63], Hsieh et al. [76], Lee et al. [77] }\end{array}$ \\
\hline Japanese macaque & $\begin{array}{l}\text { Macaca fuscata } \\
\text { Primate }\end{array}$ & HEV 3 & $+/+$ & Natural & Yamamoto et al. [78] \\
\hline Japanese white rabbit & $\begin{array}{l}\text { Oryctologus cuniculus domesticus } \\
\text { Lagomorpha }\end{array}$ & HEV 3 & $\mathrm{ND} /+$ & $\begin{array}{l}\text { Experimental } \\
\text { Natural }\end{array}$ & Xia et al. [79] \\
\hline Javan mongoose & $\begin{array}{l}\text { Herpestes javanicus } \\
\text { Carnivora }\end{array}$ & HEV 3 & $+/+$ & Natural & Li et al. [80], Nakamura et al. [81], Nidaira et al. [82] \\
\hline Mongolian gerbil & $\begin{array}{l}\text { Meriones unguiculatus } \\
\text { Rodentia }\end{array}$ & HEV 4 & $+/+$ & Experimental & Liu et al. [83] \\
\hline Moustached tamarin & $\begin{array}{l}\text { Saguinus mystax mystax } \\
\text { Primate }\end{array}$ & HEV 1,2 & $+/+$ & Experimental & Bradley et al. [56] \\
\hline $\begin{array}{l}\text { Mussels (Blue mussel, } \\
\text { Mediterranean mussel, } \\
\text { Pacific mussel), }\end{array}$ & $\begin{array}{c}\text { Mytilus edulis, Mytilus } \\
\text { galloprovincialis, Crassostrea gigas } \\
\text { Ostreoida }\end{array}$ & HEV 3 & $\mathrm{ND} /+$ & Natural & $\begin{array}{l}\text { O'Hara et al. [84], Krog et al. [85], Diez-Valcarce et al. } \\
\text { [86], Crossan et al. [30] }\end{array}$ \\
\hline Norwegian rat & $\begin{array}{c}\text { Rattus norvegicus } \\
\text { Rodentia }\end{array}$ & HEV 3 & $+/+$ & Natural & Kanai et al. [87], Lack et al. [88] \\
\hline Patas monkey & $\begin{array}{l}\text { Erythrocebus patas } \\
\text { Primate }\end{array}$ & HEV 1,2 & $\mathrm{~N} / \perp$ & Fxnerimental & Yugo et al. [50] \\
\hline $\begin{array}{l}\text { Rabbit } \\
\text { New Zealand White, Rex, } \\
\text { Japanese White }\end{array}$ & $\begin{array}{l}\text { Oryctolagus cuniculus } \\
\text { domesticus } \\
\text { Lagomorpha }\end{array}$ & HEV 3 & $+/+$ & $\begin{array}{l}\text { Experimental } \\
\text { Natural }\end{array}$ & $\begin{array}{l}\text { Cossaboom et al. [89], Izopet et al. [90], Carusoet al. } \\
\text { [91], Hammerschmidt et al. [66], Birke et al, [92], Zhao } \\
\text { et al. [93], Genget al. [94], Xia et al. [79] }\end{array}$ \\
\hline Raccoon & $\begin{array}{l}\text { Procyon lotor } \\
\text { Carnivora }\end{array}$ & $?^{\mathrm{b}}$ & $+/-$ & Natural & Dähnert et al. [95] \\
\hline Raccoon dog & $\begin{array}{l}\text { Nyctereutes procyonoides } \\
\text { Carnivora }\end{array}$ & $?^{\mathrm{b}}$ & $+/-$ & Natural & Dähnert et al. [95] \\
\hline Red deer & $\begin{array}{l}\text { Cerous elaphus } \\
\text { Artiodactyla }\end{array}$ & HEV 3 & $-1+$ & Natural & Forgách [96] et al, Anheyer-Behmenburg et al. [97] \\
\hline
\end{tabular}


Table 1. Cont

\begin{tabular}{|c|c|c|c|c|c|}
\hline \multicolumn{6}{|c|}{ Animals Susceptible to Orthohepevirus A Infection } \\
\hline Animal Species & $\begin{array}{l}\text { Scientific Name } \\
\text { Order }\end{array}$ & Genotype & $\begin{array}{c}\text { Serology/Genome } \\
\text { Detection }^{\mathrm{a}}\end{array}$ & Infection Type & References \\
\hline Reeves' muntjac & $\begin{array}{l}\text { Muntiacus reevesi } \\
\text { Artiodactyla }\end{array}$ & HEV 4 & $\mathrm{ND} /+$ & Natural & Zhang et al. [73] \\
\hline Rhesus macaque & $\begin{array}{l}\text { Macaca mulatta } \\
\text { Primate }\end{array}$ & HEV 1-4 & $+/+$ & $\begin{array}{l}\text { Experimental } \\
\text { Natural }\end{array}$ & $\begin{array}{c}\text { Arankalle et al. [39], Yamamoto et al. [78], Meng et al. } \\
\text { [49], Huang et al. [98] }\end{array}$ \\
\hline Roe deer & $\begin{array}{l}\text { Capreolus capreolus } \\
\text { Artiodactyla }\end{array}$ & HEV 3 & $-/+$ & Natural & $\begin{array}{c}\text { Reuter et al. [99], Forgách et al. [96] 2010, } \\
\text { Anheyer-Behmenburg et al. [97] }\end{array}$ \\
\hline Sheep & $\begin{array}{l}\text { Ovis aries orientalis } \\
\text { Artiodactyla }\end{array}$ & HEV 3,4 & $+/+$ & Natural & $\begin{array}{c}\text { El-Tras et al. [41], Peralta et al. [68], Sarchese et al. } \\
\text { [100], Wu et al. [101] }\end{array}$ \\
\hline Sika deer & $\begin{array}{l}\text { Cervus nippon nippon } \\
\text { Artiodactyla }\end{array}$ & HEV 3,4 & $+/+$ & Natural & Sonoda et al. [102], Zhang et al. [73] \\
\hline Silver pheasant & $\begin{array}{l}\text { Lophura nycthemera } \\
\text { Galliformes }\end{array}$ & HEV 4 & $\mathrm{ND} /+$ & Natural & Zhang et al. [36] \\
\hline Squirrel monkey & $\begin{array}{l}\text { Saimiri sciureus } \\
\text { Primate }\end{array}$ & HEV 1,2 & $+/+$ & Experimental & Tsarev et al. [55] \\
\hline Swedish moose & $\begin{array}{c}\text { Alces alces } \\
\text { Artiodactyla }\end{array}$ & HEV ? ${ }^{c}$ & $+/+$ & Natural & Lin et al. [103], Lin et al. [4] \\
\hline Tufted deer & $\begin{array}{l}\text { Elaphodus cephalophus } \\
\text { Artiodactyla }\end{array}$ & HEV 4 & $\mathrm{ND} /+$ & Natural & Zhang et al. [73] \\
\hline Vervet monkey & $\begin{array}{l}\text { Chlorocebus pygerythrus } \\
\text { Primate }\end{array}$ & HEV 1,2 & $\mathrm{ND} /+$ & Experimental & Tsarev et al. [55] \\
\hline Wild boar & $\begin{array}{l}\text { Sus scrofa } \\
\text { Artiodactyla }\end{array}$ & HEV 3,4,5,6 & $+/+$ & Natural & $\begin{array}{l}\text { Sonoda et al. [102], Martelli et al, De Deus et al. [104], } \\
\text { Adlhoch et al. [105], Wiratsudakulet al. [106], Kaci et } \\
\text { al. [107], Dong et al. [35], Takahashi et al. [108], } \\
\text { Takahashi et al. [109], Larska et al. [110], Carpentier et } \\
\text { al. [111], Anheyer-Behmenburg et al. [97] }\end{array}$ \\
\hline Yak & $\begin{array}{l}\text { Bos grunniens } \\
\text { Artiodactyla }\end{array}$ & HEV 4 & $+/+$ & Natural & Xu et al. [112] \\
\hline Yezo deer & $\begin{array}{l}\text { Cervus nippon yesoensis } \\
\text { Artiodactyla }\end{array}$ & $\operatorname{HEV} 3$ or $4 ?^{b}$ & $+/-$ & Natural & Sonoda et al. [102], Tomiyama et al. [113] \\
\hline
\end{tabular}

Table 1. Animals known to be associated with Orthohepevirus A infection. Text in bold indicates taxonomic order. For serology/genome detection " + " is any reported positive result, "-" indicates assays were performed and results were negative, "ND indicates test was not performed (Not Done)." a Serology and genomic RNA detection are a summary of all published data. Individual articles may have only included serology, only genomic RNA detection, or both. ${ }^{\mathrm{b}}$ Data presented as only serological data suggest animals were exposed to HEV but a definitive strain could not be assigned due to the single serotype of all HEV strains. ${ }^{c}$ Swedish moose HEV strain has not been assigned to a current HEV genotype and appears to cluster between Orthohepevirus A and Orthohepevirus C strains. 


\subsubsection{Genotype 3}

Genotype 3 is the most well-studied strain of zoonotic HEV. The initial discovery of genotype-3 HEV infecting swine (Sus scrofa domestica) within the commercial pork industry completely reshaped the idea of HEV as a solely human pathogen found only infecting humans in underdeveloped countries. Our current understanding of HEV is both as an endemic human pathogen in developing countries and as a zoonotic pathogen spread throughout both the developing and developed world [63,114]. For almost a decade after the discovery of genotype $3 \mathrm{HEV}$ in swine, very few animal hosts were identified. The HEV field focused primarily on primates and porcine hosts as animal reservoirs and as models for studying the disease. Only occasional hints that the HEV host range could potentially span into other species would arise in that decade, such as the serology data for rats [115], dogs (Canis lupis familiaris), cattle (Bos Taurus primigenius), and rodents [44]. The discovery of an ever-increasing range of potential hosts has begun to emerge as our general understanding of HEV has progressed to its consideration as a serious zoonotic pathogen and the technology to detect HEV infections has grown. Genotype 3 strains cross a significant range of mammalian species from the original identification in domestic pigs (Sus scrofa domestica) [63], to a number of species for which humans rely on as agriculturally important species including goats (Capra hircus aegagrus) [68,69], sheep (Ovis aries orientalis) [41,68], rabbits (Oryctologus cuniculus) [66,89-91], and horses (Equus caballus ferus) [73]. Genotype 3 strains have also been detected in many wild animal game species such as the wild boar (Sus scrofa) [102,116], deer, including sika deer (Cervus nippon nippon) [102], Yezo deer (Cervus nippon yesoensis) [102,113], Roe deer (Capreolus capreolus) [97,99], red deer (Cervus elaphus) [96,97], and in wild hares such as the European brown hare (Lepus europaeus) [66]. Genotype 3 species have even been noted in such exotic species as the Javan mongoose (Herpestes javanicus) [80-82] and even bottlenose dolphins (Tursiops truncatus) [40].

The recent findings that a genotype $3 \mathrm{HEV}$ has been attributed to infection of a bird, the Himalayan griffon (Gyps himalayensis), which was coinfected with Aspergillus [72] suggests that given the right host conditions, genotype $3 \mathrm{HEV}$ can become an opportunistic pathogen even infecting across classes such as Mammalia to Aves. Furthermore, in vitro evidence suggests the hypervariable region within the ORF 1 gene contributes to host range optimization [117]. Additionally, naturally occurring host protein insertions enhance HEV replication in cell lines derived from diverse species [118]. These two pieces of evidence suggest that the actual host range of genotype $3 \mathrm{HEV}$ might be very broad if given the opportunity to infect under the right conditions. As our ability and interest to efficiently screen the viromes of differing species increases, so will the known host range for genotype $3 \mathrm{HEV}$. Scenarios such as the discovery of genotype 3 rabbit HEV in 2009, proceeding from initial discovery, to recognition as a zoonotic pathogen, and finally development into a beneficial animal model in a short amount of time, may become more commonplace [119]. A current listing of animal species shown to be associated with HEV infection are listed throughout Table 1.

\subsubsection{Genotype $4 \mathrm{HEV}$}

Genotye 4 is similar to genotype 3 in that it has proven to be a significant zoonotic pathogen.Unlike genotype 3, genotype $4 \mathrm{HEV}$ primarily appears to be contained to Asia and more recently cases have appeared throughout Europe [120]. Like genotype $3 \mathrm{HEV}$, genotype 4 was initially discovered in domestic pigs and wild boars which serve as a primary reservoir [116]. Recent work out of China suggests cattle, including yellow cattle (Bos Taurus primigenius) [45], Holstein Frisian cattle (Bos Taurus primigenius) [46], sheep (Ovis aries orientalis) [101], and goats (Capra hircus aegagrus) [71,121] can be infected by genotype $4 \mathrm{HEV}$ and that infectious virus can potentially be inserted into the human food chain through meat and milk from these animals. In addition to these domestic animals, tufted deer (Elaphodus cephalophus) [73], Reeves' muntjac (Muntiacus reevesi), clouded leopard (Neofilis nebulosa) [73], and the Asiatic black bear (Ursus thibetanus) [36] have tested positive for genotype $4 \mathrm{HEV}$. In addition to these mammalian species, genotype $4 \mathrm{HEV}$ was detected in two birds in a zoo setting, the crowned crane 
(Balearica regulorum) and silver pheasant (Lophura nycthemera) [36]. Like genotype $3 \mathrm{HEV}$, genotype 4 appears to have a broad host range and may infect many different hosts given appropriate opportunity.

\subsubsection{Genotypes 5 and $6 \mathrm{HEV}$}

Genotypes 5 and 6 were isolated from wild boar samples in Japan [108,122]. Recent studies have shown that the virus derived from a genotype 5 infectious clone could cause infections in cynomolgus monkeys that were seronegative for HEV [59]. This research suggests that at least genotype $5 \mathrm{HEV}$ is likely a zoonotic threat to humans and suggests genotype 6 should be evaluated for its ability to infect primates.Human screening is also necessary to confirm their susceptibility. The relatively low circulation of the genotype 5 and 6 virus and geographic seclusion to Japan currently makes transmission to humans a rare occurrence.

\subsubsection{Genotypes 7 and $8 \mathrm{HEV}$}

Genotypes 7 and 8 are recently discovered HEV strains whose natural reservoirs are dromedary (Camelus dromedaries) and bactrian (Camelus bactrianus) camels, respectively [123]. The discovery of genotype $7 \mathrm{HEV}$ chronically infecting a human liver transplant patient demonstrates the ability of this virus to infect humans [77]. Additionally, genotype $8 \mathrm{HEV}$ positive samples were used to infect cynomolgus macaques which were susceptible to both acute and chronic infection [60]. Genotypes 7 and 8 should therefore be considered potential human pathogens with studies screening for genotype 8 in humans still necessary.

\subsection{Orthohepevirus B}

Orthohepevirus B, or avian HEV, isolates were first identified as causing hepatic splenomegaly syndrome or big liver and spleen disease in chickens [124]. The avian HEV genome shares $\sim 48 \%$ identity with mammalian HEVs [124]. At least four different genotypes of avian HEV have been identified from chickens worldwide: genotype 1 from chickens in Australia, genotype 2 from chickens in the USA, genotype 3 from chickens in Europe and China, and genotype 4 from chickens in Hungary and Taiwan [124-129]. An infectious clone of genotype 2 avian HEV was created [130] and has served as an important in vivo animal model system for dissecting mechanisms contributing to HEV replication and immunology and to empirically test host susceptibility. Studies with genotype 2 avian HEV showed it could infect turkeys (Meleagris gallopavo) but not rhesus monkeys or pigs [131]. A recent publication shows that in addition to turkeys; ducks, geese, and rabbits in mixed housing could be infected by genotype 3 avian HEV, raising concerns that some avian HEV strains could cross into mammalian hosts [132]. Of great concern to the commercial poultry industry is discovery of avian HEV strains that appear to correlate with enhanced pathology in chicks causing hepatic hemorrhage rupture syndrome in China [133]. More avian strains of HEV are continuing to be discovered in expanded bird species. Avian HEV isolates have now been discovered in the little egret (Egretta garzetta) with $60-70 \%$ identity to genotype 1 avian HEV, the little owl (Athene noctua), song thrush (Turdus philomelos) [134] and feral pigeon (Columba livia domestica) [135]. Even in the United States a sparrow HEV was discovered and showed higher similarity to chicken HEV strains ( $71-78 \%$ and $80 \%$ identity) than to little egret HEV (55\% and 68\% identity) [136]. The host range of Orthohepevirus B remains an emerging field. Currently reported susceptible hosts are listed in Table 2. With more thorough testing of differing avian species potentially many more avian HEV strains and hosts will be discovered. 
Table 2. Host range of Orthohepevirus B.

\begin{tabular}{|c|c|c|c|c|c|}
\hline \multicolumn{6}{|c|}{ Animals Susceptible to Orthohepevirus B } \\
\hline Animal Species & $\frac{\text { Scientific Name }}{\text { Order }}$ & Species & $\begin{array}{c}\text { Serology/Genome } \\
\text { Detection }\end{array}$ & Infection Type & References \\
\hline Chicken & $\begin{array}{l}\text { Gallus gallus } \\
\text { Galliformes }\end{array}$ & Ortho B & $+/+$ & $\begin{array}{c}\text { Natural } \\
\text { Experimental }\end{array}$ & $\begin{array}{l}\text { Haqshenas et al. } \\
\text { [124] Liu et al. }\end{array}$ \\
\hline $\begin{array}{l}\text { Common } \\
\text { buzzard }\end{array}$ & $\begin{array}{c}\text { Buteo buteo } \\
\text { Accipitriformes }\end{array}$ & Ortho B & $\mathrm{ND} /+$ & Natural & Zhang et al. [135] \\
\hline Ducks & $\begin{array}{c}\text { Anas } \\
\text { platyrhynchos }^{a} \\
\text { Anseriformes }\end{array}$ & Ortho B & $+/+$ & Natural & Liu et al. [132] \\
\hline Feral pigeon & $\begin{array}{l}\text { Columba livia } \\
\text { domestica } \\
\text { Columbiformes }\end{array}$ & Ortho B & $\mathrm{ND} /+$ & Natural & Zhang et al. [135] \\
\hline Geese & $\begin{array}{c}\text { Anser anser } \\
\text { domesticus }^{a} \\
\text { Anseriformes }\end{array}$ & Ortho B & $+/+$ & Natural & Liu et al. [132] \\
\hline Little egret & $\begin{array}{l}\text { Egretta garzetta } \\
\text { Pelicaniformes }\end{array}$ & Ortho B & $\mathrm{ND} /+$ & Natural & Reuter et al. [137] \\
\hline Little owl & $\begin{array}{l}\text { Athene noctua } \\
\text { Strigiformes }\end{array}$ & Ortho B & $\mathrm{ND} /+$ & Natural & Zhang et al. [135] \\
\hline $\begin{array}{c}\text { Rabbit } \\
\text { New Zealand } \\
\text { White }\end{array}$ & $\begin{array}{l}\text { Oryctolagus } \\
\text { cuniculus } \\
\text { Lagomorpha }\end{array}$ & Ortho B & $+/+$ & $\begin{array}{c}\text { Natural } \\
\text { Experimental }\end{array}$ & Liu et al. [132] \\
\hline Song thrush & $\begin{array}{l}\text { Turdus philomelos } \\
\text { Passeriformes }\end{array}$ & Ortho B & $\mathrm{ND} /+$ & Natural & Zhang et al. [135] \\
\hline Sparrow & $\begin{array}{l}\text { Passer domesticus } \\
\text { Passeriformes }\end{array}$ & Ortho B & $\mathrm{ND} /+$ & Natural & Yang et al. [136] \\
\hline Turkey & $\begin{array}{c}\text { Meleagris } \\
\text { gallopavo } \\
\text { Galliformes }\end{array}$ & Ortho B & $+/+$ & Experimental & Sun et al. [131] \\
\hline
\end{tabular}

Table 2 Animals associated with Orthohepevirus B infection. Names in bold represent taxonomic order. Under serology/genome detection "+" indicates any positive report for that assay within the literature, "-" represents the test being performed with negative results, ND indicates the test was not performed (Not Done). ${ }^{\text {a }}$ Exact species names are uncertain as tested animals were simply identified as duck and goose. E-mails to corresponding authors requesting clarification were not returned.

\subsection{Orthohepevirus C}

Orthohepevirus C HEV strains were initially detected around the same time as the discovery of swine HEV in 1999 when it was observed that more than $50 \%$ of rats within the United States tested positive for anti HEV antibodies [115,138], however, none tested positive for RNA. Lack of HEV RNA was likely due to PCR primer designs based on known Orthohepevirus A sequences and due to the sequence divergence of Orthohepevirus $C$ from Orthohepevirus A strains. More thorough detection methods with broad spectrum PCR primers allowed for detection and eventually sequencing of full-length viral isolates of rat HEV $[139,140]$. These isolates had approximately $50 \%$ or less sequence identity to human and avian HEV strains. Since the discovery of the first sequences of rat HEV, Orthohepevirus $C$ strains have been isolated from many different rat species [139-141], mice [142,143], greater bandicoot [134], Asian musk shrews [144], ferrets [145], voles [142,146], and mink [67,147] (Table 3). RNA from Orthohepevirus C-like strains have also been detected in feces from a red fox (Vulpes vulpes) [148], the common kestrel (Falco tinnunculus), and red-footed falcon (Falco vespertinus) [5]. Whether the fox, kestrel, or falcon-associated Orthohepevirus C HEV strains truly infect these host animals or simply pass through from consumed prey, remains debatable. Originally thought as unlikely to pose a threat to infection of higher ordered primates and humans, the recent discovery of a rat HEV strain causing chronic liver disease in a human liver transplant patient [149] greatly increases the urgency to understand this emerging human pathogen. The discovery of zoonotic potential for Orthohepevirus $C$, which had previously not been able to infect rhesus monkeys [150] experimentally, suggests that greater care is necessary to fully vet infectious potential of newly discovered HEV strains and advocates for revisiting potential host ranges of previously tested HEV strains. 
Table 3. Host range of Orthohepevirus C.

\begin{tabular}{|c|c|c|c|c|c|}
\hline \multicolumn{6}{|c|}{ Animals Susceptible to Orthohepevirus C } \\
\hline Animal Species & $\begin{array}{c}\text { Scientific Name } \\
\text { Order }\end{array}$ & Species & $\begin{array}{c}\text { Serology/Genome } \\
\text { Detection }\end{array}$ & Infection Type & References \\
\hline $\begin{array}{l}\text { Asian musk } \\
\text { shrew }\end{array}$ & $\begin{array}{l}\text { Suncus murinus } \\
\text { Eulipotyphla }\end{array}$ & Ortho C & $+/+$ & Natural & Guan et al. [144] \\
\hline Black Rat & $\begin{array}{c}\text { Rattus rattus } \\
\text { Rattus rattus } \\
\text { hainanus } \\
\text { Rodentia }\end{array}$ & Ortho C & $+/+$ & Natural & $\begin{array}{c}\text { Li et al. [134], Mulyanto et al. } \\
\text { [151], Ryll et al. [152] }\end{array}$ \\
\hline $\begin{array}{l}\text { Chevrier's Field } \\
\text { Mouse }\end{array}$ & $\begin{array}{c}\text { Apodemus } \\
\text { chevrieri } \\
\text { Rodentia }\end{array}$ & Ortho C & $\mathrm{ND} /+$ & Natural & Wang et al. [142] \\
\hline Common vole & $\begin{array}{l}\text { Microtus arvalis } \\
\text { Rodentia }\end{array}$ & Ortho C & $\mathrm{ND} /+$ & Natural & Kurucz et al. [146] \\
\hline $\begin{array}{c}\text { Delicate vesper } \\
\text { mouse }\end{array}$ & $\begin{array}{l}\text { Calomys tener } \\
\text { Rodentia }\end{array}$ & Ortho C & $\mathrm{ND} /+$ & Natural & de Souza et al. [143] \\
\hline European ferret & $\begin{array}{l}\text { Mustela putorius } \\
\text { Carnivora }\end{array}$ & Ortho C & $+/+$ & Natural & Raj et al. [145] \\
\hline European mink & $\begin{array}{l}\text { Mustelo lutreola } \\
\text { Carnivora }\end{array}$ & Ortho C & $\mathrm{ND} /+$ & Natural & Krog et al. [147] \\
\hline Farmed mink & $\begin{array}{l}\text { Neovison vison } \\
\text { Carnivora }\end{array}$ & Ortho C & $\mathrm{ND} /+$ & Natural & \\
\hline $\begin{array}{c}\text { Greater } \\
\text { bandicoot rat }\end{array}$ & $\begin{array}{l}\text { Bandicota indica } \\
\text { Rodentia }\end{array}$ & Ortho C & $+/+$ & Natural & $\begin{array}{l}\text { Xie et al. [67] } \\
\text { Li et al. [134] }\end{array}$ \\
\hline $\begin{array}{l}\text { Hairy-tailed bolo } \\
\text { mouse }\end{array}$ & $\begin{array}{l}\text { Necromys lasiurus } \\
\text { Rodentia }\end{array}$ & Ortho C & $\mathrm{ND} /+$ & Natural & de Souza et al. [143] \\
\hline House Shrew & $\begin{array}{l}\text { Suncus murinus } \\
\text { Eulipotyphla }\end{array}$ & Ortho C & $\mathrm{ND} /+$ & Natural & He et al. [153] \\
\hline Human & $\begin{array}{l}\text { Homo sapiens } \\
\text { Primate }\end{array}$ & Ortho C & $+/+$ & Natural & Sridhar et al. [149] \\
\hline Norway Rat & $\begin{array}{c}\text { Rattus norvegicus } \\
\text { Rodentia }\end{array}$ & Ortho C & $+/+$ & $\begin{array}{c}\text { Natural } \\
\text { Experimental }\end{array}$ & $\begin{array}{c}\text { Kabrane-Lazizi et al. [115], } \\
\text { Easterbrook et al. [138], Johne } \\
\text { et al. [140], Johne et al. [154], } \\
\text { Purcell et al. [150], Widen et } \\
\text { al. [155], He et al. [153] }\end{array}$ \\
\hline Peré David's Vole & $\begin{array}{l}\text { Eothenomys } \\
\text { melanogaster } \\
\text { Rodentia }\end{array}$ & Ortho C & $\mathrm{ND} /+$ & & Wang et al. [142] \\
\hline Red fox & $\begin{array}{l}\text { Vulpes vulpes } \\
\text { Carnivora }\end{array}$ & Ortho C & $\mathrm{ND} /+$ & Natural & Bodewes et al. [148] \\
\hline Taiwan rat & $\begin{array}{c}\text { Rattus rattoides } \\
\text { losea } \\
\text { Rodentia }\end{array}$ & Ortho C & $+/+$ & Natural & Li et al. [134], He et al. [153] \\
\hline $\begin{array}{l}\text { Tanezumi rat } \\
\text { (Asian rat) }\end{array}$ & $\begin{array}{l}\text { Rattus tanezumi } \\
\text { Rodentia }\end{array}$ & Ortho C & $\mathrm{ND} /+$ & Natural & He et al. [153] \\
\hline $\begin{array}{l}\text { Yellow-breasted } \\
\text { rat }\end{array}$ & $\begin{array}{l}\text { Rattus flavipectus } \\
\text { Rodentia }\end{array}$ & Ortho C & $+/+$ & Natural & Li et al. [134] \\
\hline $\begin{array}{l}\text { Table } 3 \text { Speci } \\
\text { order. Under } \\
\text { represents th } \\
\text { Serology/Ger } \\
\text { positive, gen }\end{array}$ & $\begin{array}{l}\text { reported to be in } \\
\text { erology/genome } d \\
\text { test being perform } \\
\text { me Detection sum } \\
\text { ne positive, or bot }\end{array}$ & $\begin{array}{l}\text { d with } O \\
\text { tion " }+" \\
\text { vith nega } \\
\text { izes findi }\end{array}$ & $\begin{array}{l}\text { epevirus } C \text { strains o } \\
\text { ates any positive re } \\
\text { esults, ND indicate } \\
\text { rom all literature, }\end{array}$ & $\begin{array}{l}\text { HEV. Names in } \\
\text { ort for that assa } \\
\text { the test was not } \\
\text { me article may } 1\end{array}$ & $\begin{array}{l}\text { d represent taxonomic } \\
\text { vithin the literature, "“" } \\
\text { rformed (Not Done). }{ }^{a} \\
\text { e only shown serology }\end{array}$ \\
\hline
\end{tabular}

\subsection{Orthohepevirus D}

Bat hepatitis E virus shares approximately 57.4-64.2\% identity to human HEV genotypes 1-4 [156,157]. Bat HEV has been detected in bats from the Hipposideridae, Phyllostomidae, and Vespertilionidae families [156-158] (Table 4). Although one full-length bat HEV sequence exists (JQ001749), no infectious clones currently exist. Bat HEV is not thought to transmit to humans due to its sequence divergence from human infecting strains. In addition, over 93,000 pooled human blood donations screened negative for bat HEV antibodies or RNA [157]. Further research, including an infectious clone coupled with experimental animal infections, is necessary to determine the full host range of bat $\mathrm{HEV}$. 
Table 4. Host range of Orthohepevirus D.

\begin{tabular}{|c|c|c|c|c|c|}
\hline \multicolumn{6}{|c|}{ Animals Susceptible to Orthohepevirus D } \\
\hline Animal Species & $\frac{\text { Scientific Name }}{\text { Order }}$ & Species & $\begin{array}{l}\text { Serology/Genome } \\
\text { Detection }\end{array}$ & Infection Type & References \\
\hline $\begin{array}{c}\text { Aba roundleaf } \\
\text { bat }\end{array}$ & $\begin{array}{l}\text { Hipposideros abae } \\
\text { Chiroptera }\end{array}$ & Ortho D & $\mathrm{ND} /+$ & Natural & $\begin{array}{c}\text { Drexler et al. } \\
\text { [157] }\end{array}$ \\
\hline Bechstein's bat & $\begin{array}{l}\text { Myotis bechsteinii } \\
\text { Chiroptera }\end{array}$ & Ortho D & $\mathrm{ND} /+$ & Natural & $\begin{array}{l}\text { Drexler et al. } \\
\text { [157] }\end{array}$ \\
\hline $\begin{array}{c}\text { Brown } \\
\text { long-eared bat }\end{array}$ & $\begin{array}{c}\text { Plecotus } \\
\text { sacrimontis } \\
\text { Chiroptera }\end{array}$ & Ortho D & $\mathrm{ND} /+$ & Natural & $\begin{array}{c}\text { Kobayashi et al. } \\
\text { [158] }\end{array}$ \\
\hline Daubenton's bat & $\begin{array}{l}\text { Myotis daubentonii } \\
\text { Chiroptera }\end{array}$ & Ortho D & $\mathrm{ND} /+$ & Natural & $\begin{array}{c}\text { Drexler et al. } \\
\text { [157] }\end{array}$ \\
\hline $\begin{array}{c}\text { Great stripe-faced } \\
\text { bat }\end{array}$ & $\begin{array}{l}\text { Vampyrodes } \\
\text { caraccioli } \\
\text { Chiroptera }\end{array}$ & Ortho D & $\mathrm{ND} /+$ & Natural & $\begin{array}{c}\text { Drexler et al. } \\
\text { [157] }\end{array}$ \\
\hline $\begin{array}{c}\text { Japanese } \\
\text { short-tailed bat }\end{array}$ & $\begin{array}{l}\text { Eptesicus } \\
\text { japonensis } \\
\text { Chiroptera }\end{array}$ & Ortho D & $\mathrm{ND} /+$ & Natural & $\begin{array}{c}\text { Kobayashi et al. } \\
\text { [158] }\end{array}$ \\
\hline Serotine bat & $\begin{array}{l}\text { Eptesicus serotinus } \\
\text { Chiroptera }\end{array}$ & Ortho D & $\mathrm{ND} /+$ & Natural & $\begin{array}{l}\text { Drexler et al. } \\
\text { [157] }\end{array}$ \\
\hline Whiskered bat & $\begin{array}{l}\text { Myotis davidii } \\
\text { Chiroptera }\end{array}$ & Ortho D & $\mathrm{ND} /+$ & Natural & Wang et al. [159] \\
\hline
\end{tabular}

Table 4 Species susceptible to Orthohepevirus $D$ infection. Names in bold represent taxonomic order. Under serology/genome detection " + " indicates any positive report for that assay within the literature and "ND" indicates the test was not performed (Not Done).

\subsection{Piscihepevirus}

To date the most divergent strain of HEV, cutthroat trout virus (CTV), shares approximately $40 \%$ nucleotide identity with genotype $1 \mathrm{HEV}$, necessitating phylogenetic classification into its own genus, Piscihepevirus, in the Hepeviridae family [2]. CTV has been found in Cutthroat trout (Oncorhynchus clarkii), rainbow trout (Oncorhynchus mykiss), brown trout (Salmo trutta), brook trout (Salvelinus fontinalis), golden trout (Oncorhynchus aguabonita), apache trout (Oncorhynchus apache), and gila trout (Oncorhynchus gilae) and in a single Atlantic salmon (Salmo salar) [160]. Propagation in the CHSE-214 Chinook salmon embryo cell line suggests other salmon and fish species may harbor CTV or related Hepeviruses. The ability of CTV to infect species outside of fish is thought to be unlikely but has not been directly assessed.

\section{Conclusions}

The host range of HEV is broad and continues to expand as technology and funding allows scientists to continually scan new species for this elusive RNA virus. Careful examination of HEV serological data and correlation of results with confirmatory tests such as viremia, presence of negative-strand RNA replication intermediates, or experimental infection studies should all be considered best practice approaches to identifying true hosts for HEV infection rather than suboptimal or pass-through vector hosts.

Funding: The Ohio State University Discovery Themes Initiative, Infectious Diseases Institute, and Food Animal Health Research Program start up funds.

Conflicts of Interest: The authors declare no conflict of interest.

\section{References}

1. Teshale, E.H.; Hu, D.J. Hepatitis E: Epidemiology and prevention. World J. Hepatol. 2011, 3, $285-291$. [CrossRef]

2. Batts, W.; Yun, S.; Hedrick, R.; Winton, J. A novel member of the family Hepeviridae from cutthroat trout (Oncorhynchus clarkii). Virus Res. 2011, 158, 116-123. [CrossRef] [PubMed] 
3. Reuter, G.; Boros, A.; Toth, Z.; Kapusinszky, B.; Delwart, E.; Pankovics, P. Detection of a novel RNA virus with hepatitis $E$ virus-like non-structural genome organization in amphibian, agile frog (Rana dalmatina) tadpoles. Infect. Genet. Evol. 2018, 65, 112-116. [CrossRef]

4. Lin, J.; Karlsson, M.; Olofson, A.S.; Belak, S.; Malmsten, J.; Dalin, A.M.; Widen, F.; Norder, H. High prevalence of hepatitis $\mathrm{E}$ virus in Swedish moose-a phylogenetic characterization and comparison of the virus from different regions. PLoS ONE 2015, 10, e0122102. [CrossRef] [PubMed]

5. Reuter, G.; Boros, A.; Matics, R.; Kapusinszky, B.; Delwart, E.; Pankovics, P. Divergent hepatitis E virus in birds of prey, common kestrel (Falco tinnunculus) and red-footed falcon (F. vespertinus), Hungary. Infect. Genet. Evol. 2016, 43, 343-346. [CrossRef] [PubMed]

6. Wozniakowski, G.; Samorek-Salamonowicz, E. Animal herpesviruses and their zoonotic potential for cross-species infection. Ann. Agric. Env. Med. 2015, 22, 191-194. [CrossRef]

7. Thomson, K.; Dvorzak, J.; Lagu, J.; Laku, R.; Dineen, B.; Schilperoord, M.; Muita, M.; Gikunju, S.; Waiboci, L.; Fields, B.; et al. Investigation of Hepatitis E Outbreak Among Refugees - Upper Nile, South Sudan, 2012-2013. MMWR: Morb. Mortal. Wkly. Rep. 2013, 62, 581-586.

8. Spina, A.; Lenglet, A.; Beversluis, D.; de Jong, M.; Vernier, L.; Spencer, C.; Andayi, F.; Kamau, C.; Vollmer, S.; Hogema, B.; et al. A large outbreak of Hepatitis E virus genotype 1 infection in an urban setting in Chad likely linked to household level transmission factors, 2016-2017. PLoS ONE 2017, 12, e0188240. [CrossRef]

9. Teo, C.G. Fatal outbreaks of jaundice in pregnancy and the epidemic history of hepatitis E. Epidemiol. Infect. 2012, 140, 767-787. [CrossRef] [PubMed]

10. Nan, Y.; Wu, C.; Zhao, Q.; Zhou, E.M. Zoonotic Hepatitis E Virus: An Ignored Risk for Public Health. Front. Microbiol. 2017, 8, 2396. [CrossRef]

11. Meng, X.J. Expanding Host Range and Cross-Species Infection of Hepatitis E Virus. PLoS Pathog. 2016, 12, e1005695. [CrossRef]

12. Kamar, N.; Selves, J.; Mansuy, J.M.; Ouezzani, L.; Peron, J.M.; Guitard, J.; Cointault, O.; Esposito, L.; Abravanel, F.; Danjoux, M.; et al. Hepatitis E virus and chronic hepatitis in organ-transplant recipients. $N$. Engl. J. Med. 2008, 358, 811-817. [CrossRef] [PubMed]

13. Fang, S.Y.; Han, H. Hepatitis E viral infection in solid organ transplant patients. Curr. Opin. Organ. Transpl. 2017, 22, 351-355. [CrossRef]

14. Shrestha, A.; Adhikari, A.; Bhattarai, M.; Rauniyar, R.; Debes, J.D.; Boonstra, A.; Lama, T.K.; Al Mahtab, M.; Butt, A.S.; Akbar, S.M.F.; et al. Prevalence and risk of hepatitis E virus infection in the HIV population of Nepal. Virol. J. 2017, 14, 228. [CrossRef]

15. Bai, M.J.; Zhou, N.; Dong, W.; Li, G.X.; Cong, W.; Zhu, X.Q. Seroprevalence and risk factors of hepatitis E virus infection in cancer patients in eastern China. Int. J. Infect. Dis. 2018, 71, 42-47. [CrossRef]

16. McLeish, M.J.; Fraile, A.; Garcia-Arenal, F. Ecological Complexity in Plant Virus Host Range Evolution. Adv. Virus Res. 2018, 101, 293-339. [CrossRef] [PubMed]

17. Yin, X.; Ambardekar, C.; Lu, Y.; Feng, Z. Distinct Entry Mechanisms for Nonenveloped and Quasi-Enveloped Hepatitis E Viruses. J. Virol. 2016, 90, 4232-4242. [CrossRef] [PubMed]

18. Meister, T.L.; Bruening, J.; Todt, D.; Steinmann, E. Cell culture systems for the study of hepatitis E virus. Antivir. Res. 2019, 163, 34-49. [CrossRef]

19. Rogee, S.; Le Gall, M.; Chafey, P.; Bouquet, J.; Cordonnier, N.; Frederici, C.; Pavio, N. Quantitative proteomics identifies host factors modulated during acute hepatitis E infection in swine model. J. Virol. 2014. [CrossRef] [PubMed]

20. Subramani, C.; Nair, V.P.; Anang, S.; Mandal, S.D.; Pareek, M.; Kaushik, N.; Srivastava, A.; Saha, S.; Shalimar; Nayak, B.; et al. Host-Virus Protein Interaction Network Reveals the Involvement of Multiple Host Processes in the Life Cycle of Hepatitis E Virus. mSystems 2018, 3. [CrossRef]

21. Stremlau, M.; Owens, C.M.; Perron, M.J.; Kiessling, M.; Autissier, P.; Sodroski, J. The cytoplasmic body component TRIM5alpha restricts HIV-1 infection in Old World monkeys. Nature 2004, 427, 848-853. [CrossRef]

22. Neil, S.; Bieniasz, P. Human immunodeficiency virus, restriction factors, and interferon. J. Interferon Cytokine Res. 2009, 29, 569-580. [CrossRef] [PubMed]

23. Ghimire, D.; Rai, M.; Gaur, R. Novel host restriction factors implicated in HIV-1 replication. J. Gen. Virol. 2018, 99, 435-446. [CrossRef] 
24. Aggarwal, R. Hepatitis E: Clinical presentation in disease-endemic areas and diagnosis. Semin. Liver Dis. 2013, 33, 30-40. [CrossRef]

25. Sanford, B.J.; Dryman, B.A.; Huang, Y.W.; Feagins, A.R.; Leroith, T.; Meng, X.J. Prior infection of pigs with a genotype 3 swine hepatitis $\mathrm{E}$ virus (HEV) protects against subsequent challenges with homologous and heterologous genotypes 3 and 4 human HEV. Virus Res. 2011, 159, 17-22. [CrossRef]

26. Guo, H.; Zhou, E.M.; Sun, Z.F.; Meng, X.J.; Halbur, P.G. Identification of B-cell epitopes in the capsid protein of avian hepatitis E virus (avian HEV) that are common to human and swine HEVs or unique to avian HEV. J. Gen. Virol. 2006, 87, 217-223. [CrossRef]

27. Meng, X.J. Hepatitis E virus: Animal reservoirs and zoonotic risk. Vet. Microbiol. 2010, 140, $256-265$. [CrossRef]

28. Yugo, D.M.; Cossaboom, C.M.; Heffron, C.L.; Huang, Y.W.; Kenney, S.P.; Woolums, A.R.; Hurley, D.J.; Opriessnig, T.; Li, L.; Delwart, E.; et al. Evidence for an unknown agent antigenically related to the hepatitis E virus in dairy cows in the United States. J. Med. Virol. 2019, 91, 677-686. [CrossRef] [PubMed]

29. Brassard, J.; Gagne, M.J.; Genereux, M.; Cote, C. Detection of human food-borne and zoonotic viruses on irrigated, field-grown strawberries. Appl. Environ. Microbiol. 2012, 78, 3763-3766. [CrossRef] [PubMed]

30. Crossan, C.; Baker, P.J.; Craft, J.; Takeuchi, Y.; Dalton, H.R.; Scobie, L. Hepatitis E virus genotype 3 in shellfish, United Kingdom. Emerg. Infect. Dis. 2012, 18, 2085-2087. [CrossRef]

31. Krain, L.J.; Nelson, K.E.; Labrique, A.B. Host immune status and response to hepatitis E virus infection. Clin. Microbiol. Rev. 2014, 27, 139-165. [CrossRef]

32. Wang, B.; Akanbi, O.A.; Harms, D.; Adesina, O.; Osundare, F.A.; Naidoo, D.; Deveaux, I.; Ogundiran, O.; Ugochukwu, U.; Mba, N.; et al. A new hepatitis E virus genotype 2 strain identified from an outbreak in Nigeria, 2017. Virol. J. 2018, 15, 163. [CrossRef]

33. Saad, M.D.; Hussein, H.A.; Bashandy, M.M.; Kamel, H.H.; Earhart, K.C.; Fryauff, D.J.; Younan, M.; Mohamed, A.H. Hepatitis E virus infection in work horses in Egypt. Infect. Genet. Evol. 2007, 7, 368-373. [CrossRef]

34. Doceul, V.; Bagdassarian, E.; Demange, A.; Pavio, N. Zoonotic Hepatitis E Virus: Classification, Animal Reservoirs and Transmission Routes. Viruses 2016, 8, 270. [CrossRef]

35. Dong, C.; Meng, J.; Dai, X.; Liang, J.H.; Feagins, A.R.; Meng, X.J.; Belfiore, N.M.; Bradford, C.; Corn, J.L.; Cray, C.; et al. Restricted enzooticity of hepatitis E virus genotypes 1 to 4 in the United States. J. Clin. Microbiol. 2011, 49, 4164-4172. [CrossRef]

36. Zhang, W.; Shen, Q.; Mou, J.; Yang, Z.B.; Yuan, C.L.; Cui, L.; Zhu, J.G.; Hua, X.G.; Xu, C.M.; Hu, J. Cross-species infection of hepatitis E virus in a zoo-like location, including birds. Epidemiol. Infect. 2008, 136, 1020-1026. [CrossRef]

37. Woo, P.C.; Lau, S.K.; Teng, J.L.; Tsang, A.K.; Joseph, M.; Wong, E.Y.; Tang, Y.; Sivakumar, S.; Xie, J.; Bai, R.; et al. New hepatitis E virus genotype in camels, the Middle East. Emerg. Infect. Dis. 2014, 20, 1044-1048. [CrossRef]

38. Rasche, A.; Saqib, M.; Liljander, A.M.; Bornstein, S.; Zohaib, A.; Renneker, S.; Steinhagen, K.; Wernery, R.; Younan, M.; Gluecks, I.; et al. Hepatitis E Virus Infection in Dromedaries, North and East Africa, United Arab Emirates, and Pakistan, 1983-2015. Emerg. Infect. Dis. 2016, 22, 1249-1252. [CrossRef]

39. Arankalle, V.A.; Goverdhan, M.K.; Banerjee, K. Antibodies against hepatitis E virus in Old World monkeys. J. Viral Hepat. 1994, 1, 125-129. [CrossRef]

40. Montalvo Villalba, M.C.; Cruz Martinez, D.; Ahmad, I.; Rodriguez Lay, L.A.; Bello Corredor, M.; Guevara March, C.; Martinez, L.S.; Martinez-Campo, L.S.; Jameel, S. Hepatitis E virus in bottlenose dolphins Tursiops truncatus. Dis. Aquat. Organ. 2017, 123, 13-18. [CrossRef]

41. El-Tras, W.F.; Tayel, A.A.; El-Kady, N.N. Seroprevalence of hepatitis E virus in humans and geographically matched food animals in Egypt. Zoonoses Public Health 2013, 60, 244-251. [CrossRef]

42. Liang, H.; Chen, J.; Xie, J.; Sun, L.; Ji, F.; He, S.; Zheng, Y.; Liang, C.; Zhang, G.; Su, S.; et al. Hepatitis E virus serosurvey among pet dogs and cats in several developed cities in China. PLoS ONE 2014, 9, e98068. [CrossRef] [PubMed]

43. Mochizuki, M.; Ouchi, A.; Kawakami, K.; Ishida, T.; Li, T.C.; Takeda, N.; Ikeda, H.; Tsunemitsu, H. Epidemiological study of hepatitis E virus infection of dogs and cats in Japan. Vet. Rec. 2006, 159, 853-854. 
44. Arankalle, V.A.; Joshi, M.V.; Kulkarni, A.M.; Gandhe, S.S.; Chobe, L.P.; Rautmare, S.S.; Mishra, A.C.; Padbidri, V.S. Prevalence of anti-hepatitis E virus antibodies in different Indian animal species. J. Viral Hepat. 2001, 8, 223-227. [CrossRef]

45. Yan, B.; Zhang, L.; Gong, L.; Lv, J.; Feng, Y.; Liu, J.; Song, L.; Xu, Q.; Jiang, M.; Xu, A. Hepatitis E Virus in Yellow Cattle, Shandong, Eastern China. Emerg. Infect. Dis. 2016, 22, 2211-2212. [CrossRef]

46. Huang, F.; Li, Y.; Yu, W.; Jing, S.; Wang, J.; Long, F.; He, Z.; Yang, C.; Bi, Y.; Cao, W.; et al. Excretion of infectious hepatitis E virus into milk in cows imposes high risks of zoonosis. Hepatology 2016, 64, 350-359. [CrossRef] [PubMed]

47. Yu, C.; Boon, D.; McDonald, S.L.; Myers, T.G.; Tomioka, K.; Nguyen, H.; Engle, R.E.; Govindarajan, S.; Emerson, S.U.; Purcell, R.H. Pathogenesis of hepatitis E virus and hepatitis C virus in chimpanzees: Similarities and differences. J. Virol. 2010, 84, 11264-11278. [CrossRef]

48. Arankalle, V.A.; Ticehurst, J.; Sreenivasan, M.A.; Kapikian, A.Z.; Popper, H.; Pavri, K.M.; Purcell, R.H. Aetiological association of a virus-like particle with enterically transmitted non-A, non-B hepatitis. Lancet 1988, 1, 550-554. [CrossRef]

49. Meng, X.J.; Halbur, P.G.; Shapiro, M.S.; Govindarajan, S.; Bruna, J.D.; Mushahwar, I.K.; Purcell, R.H.; Emerson, S.U. Genetic and experimental evidence for cross-species infection by swine hepatitis E virus. J. Virol. 1998, 72, 9714-9721. [PubMed]

50. Yugo, D.M.; Cossaboom, C.M.; Meng, X.J. Naturally occurring animal models of human hepatitis E virus infection. ILAR J. 2014, 55, 187-199. [CrossRef] [PubMed]

51. Zhou, C.; Li, W.; Yang, S. Analysis of hepatitis e virus-like sequence in chimpanzee. Hepat. Mon. 2014, 14, e19473. [CrossRef] [PubMed]

52. Spahr, C.; Knauf-Witzens, T.; Vahlenkamp, T.; Ulrich, R.G.; Johne, R. Hepatitis E virus and related viruses in wild, domestic and zoo animals: A review. Zoonoses Public Health 2018, 65, 11-29. [CrossRef]

53. Li, T.C.; Miyamura, T.; Takeda, N. Detection of hepatitis E virus RNA from the bivalve Yamato-Shijimi (Corbicula japonica) in Japan. Am. J. Trop. Med. Hyg. 2007, 76, 170-172. [CrossRef] [PubMed]

54. Balayan, M.S.; Andjaparidze, A.G.; Savinskaya, S.S.; Ketiladze, E.S.; Braginsky, D.M.; Savinov, A.P.; Poleschuk, V.F. Evidence for a virus in non-A, non-B hepatitis transmitted via the fecal-oral route. Intervirology 1983, 20, 23-31.

55. Tsarev, S.A.; Tsareva, T.S.; Emerson, S.U.; Govindarajan, S.; Shapiro, M.; Gerin, J.L.; Purcell, R.H. Successful passive and active immunization of cynomolgus monkeys against hepatitis E. Proc. Natl. Acad. Sci. USA 1994, 91, 10198-10202. [CrossRef]

56. Bradley, D.W.; Krawczynski, K.; Cook, E.H., Jr.; McCaustland, K.A.; Humphrey, C.D.; Spelbring, J.E.; Myint, H.; Maynard, J.E. Enterically transmitted non-A, non-B hepatitis: Serial passage of disease in cynomolgus macaques and tamarins and recovery of disease-associated 27- to 34-nm viruslike particles. Proc. Natl. Acad. Sci. USA 1987, 84, 6277-6281. [CrossRef] [PubMed]

57. Aggarwal, R.; Kamili, S.; Spelbring, J.; Krawczynski, K. Experimental studies on subclinical hepatitis E virus infection in cynomolgus macaques. J. Infect. Dis. 2001, 184, 1380-1385. [CrossRef]

58. de Carvalho, L.G.; Marchevsky, R.S.; dos Santos, D.R.; de Oliveira, J.M.; de Paula, V.S.; Lopes, L.M.; Van der Poel, W.H.; Gonzalez, J.E.; Munne, M.S.; Moran, J.; et al. Infection by Brazilian and Dutch swine hepatitis E virus strains induces haematological changes in Macaca fascicularis. BMC Infect. Dis. 2013, 13, 495. [CrossRef]

59. Li, T.C.; Bai, H.; Yoshizaki, S.; Ami, Y.; Suzaki, Y.; Doan, Y.H.; Takahashi, K.; Mishiro, S.; Takeda, N.; Wakita, T. Genotype 5 Hepatitis E Virus Produced by a Reverse Genetics System Has the Potential for Zoonotic Infection. Hepatol. Commun. 2019, 3, 160-172. [CrossRef]

60. Wang, L.; Teng, J.L.; Lau, S.K.P.; Sridhar, S.; Fu, H.; Gong, W.; Li, M.; Xu, Q.; He, Y.; Zhuang, H.; et al. Transmission of A Novel Genotype Hepatitis E Virus from Bactrian Camels to Cynomolgus Macaques. J. Virol. 2019. [CrossRef]

61. Liu, J.; Zhang, W.; Shen, Q.; Yang, S.; Huang, F.; Li, P.; Guo, X.; Yang, Z.; Cui, L.; Zhu, J.; et al. Prevalence of antibody to hepatitis E virus among pet dogs in the Jiang-Zhe area of China. Scand. J. Infect. Dis. 2009, 41, 291-295. [CrossRef]

62. McElroy, A.; Hiraide, R.; Bexfield, N.; Jalal, H.; Brownlie, J.; Goodfellow, I.; Caddy, S.L. Detection of Hepatitis E Virus Antibodies in Dogs in the United Kingdom. PLoS ONE 2015, 10, e0128703. [CrossRef] 
63. Meng, X.J.; Purcell, R.H.; Halbur, P.G.; Lehman, J.R.; Webb, D.M.; Tsareva, T.S.; Haynes, J.S.; Thacker, B.J.; Emerson, S.U. A novel virus in swine is closely related to the human hepatitis E virus. Proc. Natl. Acad. Sci. USA 1997, 94, 9860-9865. [CrossRef]

64. Garcia-Bocanegra, I.; Rivero, A.; Caballero-Gomez, J.; Lopez-Lopez, P.; Cano-Terriza, D.; Frias, M.; Jimenez-Ruiz, S.; Risalde, M.A.; Gomez-Villamandos, J.C.; Rivero-Juarez, A. Hepatitis E virus infection in equines in Spain. Transbound. Emerg. Dis. 2019, 66, 66-71. [CrossRef]

65. Ticehurst, J.; Rhodes, L.L., Jr.; Krawczynski, K.; Asher, L.V.; Engler, W.F.; Mensing, T.L.; Caudill, J.D.; Sjogren, M.H.; Hoke, C.H., Jr.; LeDuc, J.W.; et al. Infection of owl monkeys (Aotus trivirgatus) and cynomolgus monkeys (Macaca fascicularis) with hepatitis E virus from Mexico. J. Infect. Dis. 1992, 165, 835-845. [CrossRef]

66. Hammerschmidt, F.; Schwaiger, K.; Dahnert, L.; Vina-Rodriguez, A.; Hoper, D.; Gareis, M.; Groschup, M.H.; Eiden, M. Hepatitis E virus in wild rabbits and European brown hares in Germany. Zoonoses Public Health 2017, 64, 612-622. [CrossRef]

67. Xie, X.T.; Macdonald, R.E.; Tapscott, B.; Nagy, E.; Turner, P.V. Detection of Astrovirus, Rotavirus C, and Hepatitis E Viral RNA in Adult and Juvenile Farmed Mink (Neovison vison). Front. Vet. Sci 2018, 5, 132. [CrossRef]

68. Peralta, B.; Casas, M.; de Deus, N.; Martin, M.; Ortuno, A.; Perez-Martin, E.; Pina, S.; Mateu, E. Anti-HEV antibodies in domestic animal species and rodents from Spain using a genotype 3-based ELISA. Vet. Microbiol. 2009, 137, 66-73. [CrossRef]

69. Sanford, B.J.; Emerson, S.U.; Purcell, R.H.; Engle, R.E.; Dryman, B.A.; Cecere, T.E.; Buechner-Maxwell, V.; Sponenberg, D.P.; Meng, X.J. Serological evidence for a hepatitis e virus-related agent in goats in the United States. Transbound. Emerg. Dis. 2013, 60, 538-545. [CrossRef]

70. Di Martino, B.; Di Profio, F.; Melegari, I.; Sarchese, V.; Robetto, S.; Marsilio, F.; Martella, V. Detection of hepatitis E virus (HEV) in goats. Virus Res. 2016, 225, 69-72. [CrossRef]

71. Li, S.; Liu, M.; Cong, J.; Zhou, Y.; Miao, Z. Detection and Characterization of Hepatitis E Virus in Goats at Slaughterhouse in Tai'an Region, China. BioMed Res. Int. 2017, 2017, 3723650. [CrossRef]

72. Li, H.; Zhu, R.; She, R.; Zhang, C.; Shi, R.; Li, W.; Du, F.; Wu, Q.; Hu, F.; Zhang, Y.; et al. Case Report Associated with Aspergillosis and Hepatitis E Virus Coinfection in Himalayan Griffons. BioMed Res. Int. 2015, 2015, 287315. [CrossRef]

73. Zhang, W.; Shen, Q.; Mou, J.; Gong, G.; Yang, Z.; Cui, L.; Zhu, J.; Ju, G.; Hua, X. Hepatitis E virus infection among domestic animals in eastern China. Zoonoses Public Health 2008, 55, 291-298. [CrossRef]

74. Arankalle, V.A.; Paranjape, S.; Emerson, S.U.; Purcell, R.H.; Walimbe, A.M. Phylogenetic analysis of hepatitis E virus isolates from India (1976-1993). J. Gen. Virol. 1999, 80, 1691-1700. [CrossRef]

75. Huang, C.C.; Nguyen, D.; Fernandez, J.; Yun, K.Y.; Fry, K.E.; Bradley, D.W.; Tam, A.W.; Reyes, G.R. Molecular cloning and sequencing of the Mexico isolate of hepatitis E virus (HEV). Virology 1992, 191, 550-558. [CrossRef]

76. Hsieh, S.Y.; Meng, X.J.; Wu, Y.H.; Liu, S.T.; Tam, A.W.; Lin, D.Y.; Liaw, Y.F. Identity of a novel swine hepatitis E virus in Taiwan forming a monophyletic group with Taiwan isolates of human hepatitis E virus. J. Clin. Microbiol. 1999, 37, 3828-3834.

77. Lee, G.H.; Tan, B.H.; Teo, E.C.; Lim, S.G.; Dan, Y.Y.; Wee, A.; Aw, P.P.; Zhu, Y.; Hibberd, M.L.; Tan, C.K.; et al. Chronic Infection With Camelid Hepatitis E Virus in a Liver Transplant Recipient Who Regularly Consumes Camel Meat and Milk. Gastroenterology 2016, 150, 355-357.e353. [CrossRef] [PubMed]

78. Yamamoto, H.; Suzuki, J.; Matsuda, A.; Ishida, T.; Ami, Y.; Suzaki, Y.; Adachi, I.; Wakita, T.; Takeda, N.; Li, T.C. Hepatitis E virus outbreak in monkey facility, Japan. Emerg. Infect. Dis. 2012, 18, 2032-2034. [CrossRef]

79. Xia, J.; Zeng, H.; Liu, L.; Zhang, Y.; Liu, P.; Geng, J.; Wang, L.; Wang, L.; Zhuang, H. Swine and rabbits are the main reservoirs of hepatitis E virus in China: Detection of HEV RNA in feces of farmed and wild animals. Arch. Virol. 2015, 160, 2791-2798. [CrossRef]

80. Li, T.C.; Saito, M.; Ogura, G.; Ishibashi, O.; Miyamura, T.; Takeda, N. Serologic evidence for hepatitis E virus infection in mongoose. Am. J. Trop. Med. Hyg. 2006, 74, 932-936. [CrossRef]

81. Nakamura, M.; Takahashi, K.; Taira, K.; Taira, M.; Ohno, A.; Sakugawa, H.; Arai, M.; Mishiro, S. Hepatitis E virus infection in wild mongooses of Okinawa, Japan: Demonstration of anti-HEV antibodies and a full-genome nucleotide sequence. Hepatol. Res. 2006, 34, 137-140. [CrossRef] 
82. Nidaira, M.; Takahashi, K.; Ogura, G.; Taira, K.; Okano, S.; Kudaka, J.; Itokazu, K.; Mishiro, S.; Nakamura, M. Detection and phylogenetic analysis of hepatitis E viruses from mongooses in Okinawa, Japan. J. Vet. Med. Sci. 2012, 74, 1665-1668. [CrossRef] [PubMed]

83. Liu, T.; Xiao, P.; Li, R.; She, R.; Tian, J.; Wang, J.; Mao, J.; Yin, J.; Shi, R. Increased Mast Cell Activation in Mongolian Gerbils Infected by Hepatitis E Virus. Front. Microbiol 2018, 9, 2226. [CrossRef]

84. O'Hara, Z.; Crossan, C.; Craft, J.; Scobie, L. First Report of the Presence of Hepatitis E Virus in Scottish-Harvested Shellfish Purchased at Retail Level. Food Env. Virol. 2018, 10, 217-221. [CrossRef]

85. Krog, J.S.; Larsen, L.E.; Schultz, A.C. Enteric porcine viruses in farmed shellfish in Denmark. Int. J. Food Microbiol. 2014, 186, 105-109. [CrossRef]

86. Diez-Valcarce, M.; Kokkinos, P.; Soderberg, K.; Bouwknegt, M.; Willems, K.; de Roda-Husman, A.M.; von Bonsdorff, C.H.; Bellou, M.; Hernandez, M.; Maunula, L.; et al. Occurrence of human enteric viruses in commercial mussels at retail level in three European countries. Food Env. Virol. 2012, 4, 73-80. [CrossRef]

87. Kanai, Y.; Miyasaka, S.; Uyama, S.; Kawami, S.; Kato-Mori, Y.; Tsujikawa, M.; Yunoki, M.; Nishiyama, S.; Ikuta, K.; Hagiwara, K. Hepatitis E virus in Norway rats (Rattus norvegicus) captured around a pig farm. BMC Res. Notes 2012, 5, 4. [CrossRef]

88. Lack, J.B.; Volk, K.; Van Den Bussche, R.A. Hepatitis E virus genotype 3 in wild rats, United States. Emerg. Infect. Dis. 2012, 18, 1268-1273. [CrossRef]

89. Cossaboom, C.M.; Cordoba, L.; Dryman, B.A.; Meng, X.J. Hepatitis E virus in rabbits, Virginia, USA. Emerg. Infect. Dis. 2011, 17, 2047-2049. [CrossRef]

90. Izopet, J.; Dubois, M.; Bertagnoli, S.; Lhomme, S.; Marchandeau, S.; Boucher, S.; Kamar, N.; Abravanel, F.; Guerin, J.L. Hepatitis E virus strains in rabbits and evidence of a closely related strain in humans, France. Emerg. Infect. Dis. 2012, 18, 1274-1281. [CrossRef]

91. Caruso, C.; Modesto, P.; Prato, R.; Scaglione, F.E.; De Marco, L.; Bollo, E.; Acutis, P.L.; Masoero, L.; Peletto, S. Hepatitis E Virus: First Description in a Pet House Rabbit. A New Transmission Route for Human? Transbound. Emerg. Dis. 2015, 62, 229-232. [CrossRef] [PubMed]

92. Birke, L.; Cormier, S.A.; You, D.; Stout, R.W.; Clement, C.; Johnson, M.; Thompson, H. Hepatitis E antibodies in laboratory rabbits from 2 US vendors. Emerg. Infect. Dis. 2014, 20, 693-696. [CrossRef] [PubMed]

93. Zhao, C.; Ma, Z.; Harrison, T.J.; Feng, R.; Zhang, C.; Qiao, Z.; Fan, J.; Ma, H.; Li, M.; Song, A.; et al. A novel genotype of hepatitis E virus prevalent among farmed rabbits in China. J. Med. Virol. 2009, 81, 1371-1379. [CrossRef] [PubMed]

94. Geng, J.; Wang, L.; Wang, X.; Fu, H.; Bu, Q.; Zhu, Y.; Zhuang, H. Study on prevalence and genotype of hepatitis E virus isolated from Rex Rabbits in Beijing, China. J. Viral Hepat. 2011, 18, 661-667. [CrossRef] [PubMed]

95. Dahnert, L.; Conraths, F.J.; Reimer, N.; Groschup, M.H.; Eiden, M. Molecular and serological surveillance of Hepatitis E virus in wild and domestic carnivores in Brandenburg, Germany. Transbound. Emerg. Dis. 2018, 65, 1377-1380. [CrossRef]

96. Forgach, P.; Nowotny, N.; Erdelyi, K.; Boncz, A.; Zentai, J.; Szucs, G.; Reuter, G.; Bakonyi, T. Detection of hepatitis E virus in samples of animal origin collected in Hungary. Vet. Microbiol. 2010, 143, 106-116. [CrossRef] [PubMed]

97. Anheyer-Behmenburg, H.E.; Szabo, K.; Schotte, U.; Binder, A.; Klein, G.; Johne, R. Hepatitis E Virus in Wild Boars and Spillover Infection in Red and Roe Deer, Germany, 2013-2015. Emerg. Infect. Dis. 2017, 23, 130-133. [CrossRef] [PubMed]

98. Huang, F.; Yu, W.; Hua, X.; Jing, S.; Zeng, W.; He, Z. Seroepidemiology and molecular characterization of hepatitis E Virus in Macaca mulatta from a village in Yunnan, China, where infection with this virus is endemic. Hepat. Mon. 2011, 11, 745-749. [CrossRef]

99. Reuter, G.; Fodor, D.; Forgach, P.; Katai, A.; Szucs, G. Characterization and zoonotic potential of endemic hepatitis E virus (HEV) strains in humans and animals in Hungary. J. Clin. Virol. 2009, 44, 277-281. [CrossRef]

100. Sarchese, V.; Di Profio, F.; Melegari, I.; Palombieri, A.; Sanchez, S.B.; Arbuatti, A.; Ciuffetelli, M.; Marsilio, F.; Martella, V.; Di Martino, B. Hepatitis E virus in sheep in Italy. Transbound. Emerg. Dis. 2019. [CrossRef] [PubMed]

101. Wu, J.; Si, F.; Jiang, C.; Li, T.; Jin, M. Molecular detection of hepatitis E virus in sheep from southern Xinjiang, China. Virus Genes 2015, 50, 410-417. [CrossRef] [PubMed] 
102. Sonoda, H.; Abe, M.; Sugimoto, T.; Sato, Y.; Bando, M.; Fukui, E.; Mizuo, H.; Takahashi, M.; Nishizawa, T.; Okamoto, H. Prevalence of hepatitis E virus (HEV) Infection in wild boars and deer and genetic identification of a genotype 3 HEV from a boar in Japan. J. Clin. Microbiol. 2004, 42, 5371-5374. [CrossRef] [PubMed]

103. Lin, J.; Norder, H.; Uhlhorn, H.; Belak, S.; Widen, F. Novel hepatitis E like virus found in Swedish moose. J. Gen. Virol. 2014, 95, 557-570. [CrossRef]

104. De Deus, N.; Peralta, B.; Pina, S.; Allepuz, A.; Mateu, E.; Vidal, D.; Ruiz-Fons, F.; Martin, M.; Gortazar, C.; Segales, J. Epidemiological study of hepatitis E virus infection in European wild boars (Sus scrofa) in Spain. Vet. Microbiol. 2008, 129, 163-170. [CrossRef] [PubMed]

105. Adlhoch, C.; Wolf, A.; Meisel, H.; Kaiser, M.; Ellerbrok, H.; Pauli, G. High HEV presence in four different wild boar populations in East and West Germany. Vet. Microbiol. 2009, 139, 270-278. [CrossRef] [PubMed]

106. Wiratsudakul, A.; Sariya, L.; Prompiram, P.; Tantawet, S.; Suraruangchai, D.; Sedwisai, P.; Sangkachai, N.; Suksai, P.; Ratanakorn, P. Detection and phylogenetic characterization of hepatitis E virus genotype 3 in a captive wild boar in Thailand. J. Zoo Wildl Med. 2012, 43, 640-644. [CrossRef]

107. Kaci, S.; Nockler, K.; Johne, R. Detection of hepatitis E virus in archived German wild boar serum samples. Vet. Microbiol. 2008, 128, 380-385. [CrossRef]

108. Takahashi, M.; Nishizawa, T.; Sato, H.; Sato, Y.; Jirintai; Nagashima, S.; Okamoto, H. Analysis of the full-length genome of a hepatitis E virus isolate obtained from a wild boar in Japan that is classifiable into a novel genotype. J. Gen. Virol. 2011, 92, 902-908. [CrossRef]

109. Takahashi, M.; Nishizawa, T.; Nagashima, S.; Jirintai, S.; Kawakami, M.; Sonoda, Y.; Suzuki, T.; Yamamoto, S.; Shigemoto, K.; Ashida, K.; et al. Molecular characterization of a novel hepatitis E virus (HEV) strain obtained from a wild boar in Japan that is highly divergent from the previously recognized HEV strains. Virus Res. 2014, 180, 59-69. [CrossRef]

110. Larska, M.; Krzysiak, M.K.; Jablonski, A.; Kesik, J.; Bednarski, M.; Rola, J. Hepatitis E virus antibody prevalence in wildlife in Poland. Zoonoses Public Health 2015, 62, 105-110. [CrossRef]

111. Carpentier, A.; Chaussade, H.; Rigaud, E.; Rodriguez, J.; Berthault, C.; Boue, F.; Tognon, M.; Touze, A.; Garcia-Bonnet, N.; Choutet, P.; et al. High hepatitis E virus seroprevalence in forestry workers and in wild boars in France. J. Clin. Microbiol. 2012, 50, 2888-2893. [CrossRef]

112. Xu, F.; Pan, Y.; Baloch, A.R.; Tian, L.; Wang, M.; Na, W.; Ding, L.; Zeng, Q. Hepatitis E virus genotype 4 in yak, northwestern China. Emerg. Infect. Dis. 2014, 20, 2182-2184. [CrossRef] [PubMed]

113. Tomiyama, D.; Inoue, E.; Osawa, Y.; Okazaki, K. Serological evidence of infection with hepatitis E virus among wild Yezo-deer, Cervus nippon yesoensis, in Hokkaido, Japan. J. Viral Hepat. 2009, 16, 524-528. [CrossRef]

114. Meng, X.J. Novel strains of hepatitis E virus identified from humans and other animal species: Is hepatitis E a zoonosis? J. Hepatol. 2000, 33, 842-845. [CrossRef]

115. Kabrane-Lazizi, Y.; Fine, J.B.; Elm, J.; Glass, G.E.; Higa, H.; Diwan, A.; Gibbs, C.J., Jr.; Meng, X.J.; Emerson, S.U.; Purcell, R.H. Evidence for widespread infection of wild rats with hepatitis E virus in the United States. Am. J. Trop. Med. Hyg. 1999, 61, 331-335. [CrossRef]

116. Pavio, N.; Meng, X.J.; Renou, C. Zoonotic hepatitis E: Animal reservoirs and emerging risks. Vet. Res. 2010, 41, 46. [CrossRef] [PubMed]

117. Pudupakam, R.S.; Kenney, S.P.; Cordoba, L.; Huang, Y.W.; Dryman, B.A.; Leroith, T.; Pierson, F.W.; Meng, X.J. Mutational analysis of the hypervariable region of hepatitis $\mathrm{E}$ virus reveals its involvement in the efficiency of viral RNA replication. J. Virol. 2011, 85, 10031-10040. [CrossRef] [PubMed]

118. Shukla, P.; Nguyen, H.T.; Torian, U.; Engle, R.E.; Faulk, K.; Dalton, H.R.; Bendall, R.P.; Keane, F.E.; Purcell, R.H.; Emerson, S.U. Cross-species infections of cultured cells by hepatitis $\mathrm{E}$ virus and discovery of an infectious virus-host recombinant. Proc. Natl. Acad. Sci. USA 2011, 108, 2438-2443. [CrossRef] [PubMed]

119. Wang, L.; Liu, L.; Wang, L. An overview: Rabbit hepatitis E virus (HEV) and rabbit providing an animal model for HEV study. Rev. Med. Virol. 2018, 28. [CrossRef] [PubMed]

120. Forni, D.; Cagliani, R.; Clerici, M.; Sironi, M. Origin and dispersal of Hepatitis E virus. Emerg. Microbes Infect 2018, 7, 11. [CrossRef]

121. Long, F.; Yu, W.; Yang, C.; Wang, J.; Li, Y.; Li, Y.; Huang, F. High prevalence of hepatitis E virus infection in goats. J. Med. Virol. 2017, 89, 1981-1987. [CrossRef] [PubMed] 
122. Takahashi, M.; Tamura, K.; Hoshino, Y.; Nagashima, S.; Yazaki, Y.; Mizuo, H.; Iwamoto, S.; Okayama, M.; Nakamura, Y.; Kajii, E.; et al. A nationwide survey of hepatitis E virus infection in the general population of Japan. J. Med. Virol. 2010, 82, 271-281. [CrossRef]

123. Sridhar, S.; Teng, J.L.L.; Chiu, T.H.; Lau, S.K.P.; Woo, P.C.Y. Hepatitis E Virus Genotypes and Evolution: Emergence of Camel Hepatitis E Variants. Int. J. Mol. Sci. 2017, 18, 869. [CrossRef] [PubMed]

124. Haqshenas, G.; Shivaprasad, H.L.; Woolcock, P.R.; Read, D.H.; Meng, X.J. Genetic identification and characterization of a novel virus related to human hepatitis $E$ virus from chickens with hepatitis-splenomegaly syndrome in the United States. J. Gen. Virol. 2001, 82, 2449-2462. [CrossRef] [PubMed]

125. Banyai, K.; Toth, A.G.; Ivanics, E.; Glavits, R.; Szentpali-Gavaller, K.; Dan, A. Putative novel genotype of avian hepatitis E virus, Hungary, 2010. Emerg. Infect. Dis. 2012, 18, 1365-1368. [CrossRef] [PubMed]

126. Bilic, I.; Jaskulska, B.; Basic, A.; Morrow, C.J.; Hess, M. Sequence analysis and comparison of avian hepatitis E viruses from Australia and Europe indicate the existence of different genotypes. J. Gen. Virol. 2009, 90, 863-873. [CrossRef]

127. Hsu, I.W.; Tsai, H.J. Avian hepatitis E virus in chickens, Taiwan, 2013. Emerg. Infect. Dis. 2014, 20, $149-151$. [CrossRef] [PubMed]

128. Marek, A.; Bilic, I.; Prokofieva, I.; Hess, M. Phylogenetic analysis of avian hepatitis E virus samples from European and Australian chicken flocks supports the existence of a different genus within the Hepeviridae comprising at least three different genotypes. Vet. Microbiol. 2010, 145, 54-61. [CrossRef]

129. Zhao, Q.; Zhou, E.M.; Dong, S.W.; Qiu, H.K.; Zhang, L.; Hu, S.B.; Zhao, F.F.; Jiang, S.J.; Sun, Y.N. Analysis of avian hepatitis E virus from chickens, China. Emerg. Infect. Dis. 2010, 16, 1469-1472. [CrossRef]

130. Huang, F.F.; Pierson, F.W.; Toth, T.E.; Meng, X.J. Construction and characterization of infectious cDNA clones of a chicken strain of hepatitis E virus (HEV), avian HEV. J. Gen. Virol. 2005, 86, 2585-2593. [CrossRef]

131. Sun, Z.F.; Larsen, C.T.; Huang, F.F.; Billam, P.; Pierson, F.W.; Toth, T.E.; Meng, X.J. Generation and infectivity titration of an infectious stock of avian hepatitis E virus (HEV) in chickens and cross-species infection of turkeys with avian HEV. J. Clin. Microbiol. 2004, 42, 2658-2662. [CrossRef] [PubMed]

132. Liu, B.; Fan, M.; Zhang, B.; Chen, Y.; Sun, Y.; Du, T.; Nan, Y.; Zhou, E.M.; Zhao, Q. Avian hepatitis E virus infection of duck, goose, and rabbit in northwest China. Emerg. Microbes Infect. 2018, 7, 76. [CrossRef]

133. Su, Q.; Li, Y.; Meng, F.; Cui, Z.; Chang, S.; Zhao, P. Hepatic rupture hemorrhage syndrome in chickens caused by a novel genotype avian hepatitis E virus. Vet. Microbiol. 2018, 222, 91-97. [CrossRef]

134. Li, W.; Guan, D.; Su, J.; Takeda, N.; Wakita, T.; Li, T.C.; Ke, C.W. High prevalence of rat hepatitis E virus in wild rats in China. Vet. Microbiol. 2013, 165, 275-280. [CrossRef] [PubMed]

135. Zhang, X.; Bilic, I.; Troxler, S.; Hess, M. Evidence of genotypes 1 and 3 of avian hepatitis E virus in wild birds. Virus Res. 2017, 228, 75-78. [CrossRef] [PubMed]

136. Yang, C.; Wang, L.; Shen, H.; Zheng, Y.; Gauger, P.C.; Chen, Q.; Zhang, J.; Yoon, K.J.; Harmon, K.M.; Main, R.G.; et al. Detection and genomic characterization of new avian-like hepatitis E virus in a sparrow in the United States. Arch. Virol. 2018, 163, 2861-2864. [CrossRef]

137. Reuter, G.; Boros, A.; Matics, R.; Kapusinszky, B.; Delwart, E.; Pankovics, P. A novel avian-like hepatitis E virus in wild aquatic bird, little egret (Egretta garzetta), in Hungary. Infect. Genet. Evol. 2016, 46, 74-77. [CrossRef]

138. Easterbrook, J.D.; Kaplan, J.B.; Vanasco, N.B.; Reeves, W.K.; Purcell, R.H.; Kosoy, M.Y.; Glass, G.E.; Watson, J.; Klein, S.L. A survey of zoonotic pathogens carried by Norway rats in Baltimore, Maryland, USA. Epidemiol. Infect. 2007, 135, 1192-1199. [CrossRef] [PubMed]

139. Johne, R.; Plenge-Bonig, A.; Hess, M.; Ulrich, R.G.; Reetz, J.; Schielke, A. Detection of a novel hepatitis E-like virus in faeces of wild rats using a nested broad-spectrum RT-PCR. J. Gen. Virol. 2010, 91, 750-758. [CrossRef] [PubMed]

140. Johne, R.; Heckel, G.; Plenge-Bonig, A.; Kindler, E.; Maresch, C.; Reetz, J.; Schielke, A.; Ulrich, R.G. Novel hepatitis E virus genotype in Norway rats, Germany. Emerg. Infect. Dis. 2010, 16, 1452-1455. [CrossRef]

141. Li, T.C.; Yoshizaki, S.; Ami, Y.; Suzaki, Y.; Yasuda, S.P.; Yoshimatsu, K.; Arikawa, J.; Takeda, N.; Wakita, T. Susceptibility of laboratory rats against genotypes 1,3,4, and rat hepatitis E viruses. Vet. Microbiol. 2013, 163, 54-61. [CrossRef] 
142. Wang, B.; Li, W.; Zhou, J.H.; Li, B.; Zhang, W.; Yang, W.H.; Pan, H.; Wang, L.X.; Bock, C.T.; Shi, Z.L.; et al. Chevrier's Field Mouse (Apodemus chevrieri) and Pere David's Vole (Eothenomys melanogaster) in China Carry Orthohepeviruses that form Two Putative Novel Genotypes Within the Species Orthohepevirus C. Virol. Sin. 2018, 33, 44-58. [CrossRef]

143. de Souza, W.M.; Romeiro, M.F.; Sabino-Santos, G., Jr.; Maia, F.G.M.; Fumagalli, M.J.; Modha, S.; Nunes, M.R.T.; Murcia, P.R.; Figueiredo, L.T.M. Novel orthohepeviruses in wild rodents from Sao Paulo State, Brazil. Virology 2018, 519, 12-16. [CrossRef]

144. Guan, D.; Li, W.; Su, J.; Fang, L.; Takeda, N.; Wakita, T.; Li, T.C.; Ke, C. Asian musk shrew as a reservoir of rat hepatitis E virus, China. Emerg. Infect. Dis. 2013, 19, 1341-1343. [CrossRef]

145. Raj, V.S.; Smits, S.L.; Pas, S.D.; Provacia, L.B.; Moorman-Roest, H.; Osterhaus, A.D.; Haagmans, B.L. Novel hepatitis E virus in ferrets, the Netherlands. Emerg. Infect. Dis. 2012, 18, 1369-1370. [CrossRef]

146. Kurucz, K.; Hederics, D.; Bali, D.; Kemenesi, G.; Horvath, G.; Jakab, F. Hepatitis E virus in Common voles (Microtus arvalis) from an urban environment, Hungary: Discovery of a Cricetidae-specific genotype of Orthohepevirus C. Zoonoses Public Health 2019, 66, 259-263. [CrossRef]

147. Krog, J.S.; Breum, S.O.; Jensen, T.H.; Larsen, L.E. Hepatitis E virus variant in farmed mink, Denmark. Emerg. Infect. Dis. 2013, 19, 2028-2030. [CrossRef]

148. Bodewes, R.; van der Giessen, J.; Haagmans, B.L.; Osterhaus, A.D.; Smits, S.L. Identification of multiple novel viruses, including a parvovirus and a hepevirus, in feces of red foxes. J. Virol. 2013, 87, 7758-7764. [CrossRef]

149. Sridhar, S.; Yip, C.C.Y.; Wu, S.; Cai, J.; Zhang, A.J.; Leung, K.H.; Chung, T.W.H.; Chan, J.F.W.; Chan, W.M.; Teng, J.L.L.; et al. Rat Hepatitis E Virus as Cause of Persistent Hepatitis after Liver Transplant. Emerg. Infect. Dis. 2018, 24, 2241-2250. [CrossRef]

150. Purcell, R.H.; Engle, R.E.; Rood, M.P.; Kabrane-Lazizi, Y.; Nguyen, H.T.; Govindarajan, S.; St Claire, M.; Emerson, S.U. Hepatitis E virus in rats, Los Angeles, California, USA. Emerg. Infect. Dis. 2011, 17, 2216-2222. [CrossRef]

151. Mulyanto; Suparyatmo, J.B.; Andayani, I.G.; Khalid; Takahashi, M.; Ohnishi, H.; Jirintai, S.; Nagashima, S.; Nishizawa, T.; Okamoto, H. Marked genomic heterogeneity of rat hepatitis E virus strains in Indonesia demonstrated on a full-length genome analysis. Virus Res. 2014, 179, 102-112. [CrossRef]

152. Ryll, R.; Bernstein, S.; Heuser, E.; Schlegel, M.; Dremsek, P.; Zumpe, M.; Wolf, S.; Pepin, M.; Bajomi, D.; Muller, G.; et al. Detection of rat hepatitis E virus in wild Norway rats (Rattus norvegicus) and Black rats (Rattus rattus) from 11 European countries. Vet. Microbiol. 2017, 208, 58-68. [CrossRef] [PubMed]

153. He, W.; Wen, Y.; Xiong, Y.; Zhang, M.; Cheng, M.; Chen, Q. The prevalence and genomic characteristics of hepatitis E virus in murine rodents and house shrews from several regions in China. BMC Vet. Res. 2018, 14, 414. [CrossRef] [PubMed]

154. Johne, R.; Dremsek, P.; Kindler, E.; Schielke, A.; Plenge-Bonig, A.; Gregersen, H.; Wessels, U.; Schmidt, K.; Rietschel, W.; Groschup, M.H.; et al. Rat hepatitis E virus: Geographical clustering within Germany and serological detection in wild Norway rats (Rattus norvegicus). Infect. Genet. Evol. 2012, 12, 947-956. [CrossRef] [PubMed]

155. Widen, F.; Ayral, F.; Artois, M.; Olofson, A.S.; Lin, J. PCR detection and analysis of potentially zoonotic Hepatitis E virus in French rats. Virol. J. 2014, 11, 90. [CrossRef]

156. Johne, R.; Dremsek, P.; Reetz, J.; Heckel, G.; Hess, M.; Ulrich, R.G. Hepeviridae: An expanding family of vertebrate viruses. Infect. Genet. Evol. 2014, 27, 212-229. [CrossRef]

157. Drexler, J.F.; Seelen, A.; Corman, V.M.; Fumie Tateno, A.; Cottontail, V.; Melim Zerbinati, R.; Gloza-Rausch, F.; Klose, S.M.; Adu-Sarkodie, Y.; Oppong, S.K.; et al. Bats worldwide carry hepatitis E virus-related viruses that form a putative novel genus within the family Hepeviridae. J. Virol. 2012, 86, 9134-9147. [CrossRef] [PubMed]

158. Kobayashi, T.; Murakami, S.; Yamamoto, T.; Mineshita, K.; Sakuyama, M.; Sasaki, R.; Maeda, K.; Horimoto, T. Detection of bat hepatitis E virus RNA in microbats in Japan. Virus Genes 2018, 54, 599-602. [CrossRef] 
159. Wang, B.; Yang, X.L.; Li, W.; Zhu, Y.; Ge, X.Y.; Zhang, L.B.; Zhang, Y.Z.; Bock, C.T.; Shi, Z.L. Detection and genome characterization of four novel bat hepadnaviruses and a hepevirus in China. Virol. J. 2017, 14, 40. [CrossRef] [PubMed]

160. Kibenge, F.S.; Whyte, S.K.; Hammell, K.L.; Rainnie, D.; Kibenge, M.T.; Martin, C.K. A dual infection of infectious salmon anaemia (ISA) virus and a togavirus-like virus in ISA of Atlantic salmon Salmo salar in New Brunswick, Canada. Dis. Aquat. Organ. 2000, 42, 11-15. [CrossRef] 